\title{
Geleneğin İcadında Karacaşehir Camii Örneği
}

\section{Creating The Tradition an Example of Karacaşehir Mosque}

\section{Zeynep ERTUĞRUL*}

\author{
Anadolu Üniversitesi, Edebiyat Fakültesi, Sanat Tarihi Bölümü, zkedik@anadolu.edu.tr*
}

ORCID Numarası | ORCID Number : 0000-0001-5739-407X

\begin{abstract}
$\ddot{O Z Z}$
Karacaşehir Köyü Camisi Erken Osmanlı Dönemi'nin önemli yerleşimlerinden Eskişehir'deki Karacahisar Kalesi’nin de üzerinde yer aldığı platonun eteklerinde bulunmaktadır. Dikdörtgen planlı yapı, ahşaptan iki ayak ile taşınan kadınlar mahfiline, sade, bezemesiz yarım daire bir mihrap nişine sahiptir ve kuzey batı yönünde tek minarelidir. Bu küçük ölçekli sayılabilecek caminin en dikkat çekici mimari verileri harimin çökertme tavanı, minarenin şerefesi altında görülen testere dişi uygulaması ve kubbe benzeri külahıdır. Yapı Aşıkpaşazade'nin Osmanlı Devletinin kuruluşunu anlattığı eserinde bahsedilen, ilk hutbenin okunduğu yer olarak kabul edilmektedir. Günümüzde Karacaşehir'de düzenlenen anma etkinlikleri ile caminin bu özelliği giderek ön plana çıkarılmıştır. Ancak hem mimari veriler hem de özellikle 19. Yüzyıla tarihlenen arşiv belgeleri ayakta olan yapının tarihinin bu kadar eskiye götürülmesini zorlaştırmaktadır. Yapı ile ilgili bu tarih karmaşasının en önemli nedeni Osmanlı kroniklerinde ve Devlet Arşivlerindeki Osmanlı belgelerinde Karacaşehir ve Karacahisar adlarının zaman zaman birbiri yerine kullanılması ve Karacaşehir adı verilen bölgenin neresi olduğunun tam olarak netleştirilememesidir. Karacaşehir Köyünün tarihi arşiv belgelerine göre 15. yüzyılın ortalarına kadar indirilse de bu tarihten günümüze gelebilen mimari bir veri bulunmamaktadır. Dolayısıyla günümüzdeki Karacaşehir yerleşiminin 1843 yılında Karakeçili aşiretinin buraya yerleștirilmesi ile yeniden canlandırıldığ 1 ve bugün ayakta olan Karacaşehir Cami'sininde yıkılmış olan bir başka cami yapısının yerine 19. yüzyılda inşa edilmiş olduğu söylenilebilir.
\end{abstract}

Anahtar Kelimeler: Karacaşehir, Camii, Eskişehir, Osmanlı, Karacahisar

\begin{abstract}
Karacaşehir Village Mosque is at the foot of the plateau on where Karacahisar Castle in Eskişehir, one of the important settlements of early Ottoman archeology was on. It has a simple, unadorned semi-circle mihrab niche and a single minaret facing north-west with a rectangular plan and a balcony in the form of a balcony carried with two legs from wood. The most striking architectural data of this small-scale mosque is the collapsing ceiling of the harim, saw-toothed ornament under the balcony of the minaret and the domed cover of the minaret.

The building is regarded as the place where the first sermon was read in the Ottoman Empire, which is mentioned in Aş1kpaşazade's book on the establishment of Ottoman State. Various activities nowadays performed here emphasize this feature of the mosque. But both architectural data and especially the archives from 19Th century make it very difficult to date this mosque so old. The main reason on confusion about the date of the building is the names of Karacaşehir and Karacahisar are used interchangeable in the Ottoman chronicles and official archives and whereabout of the place named Karacaşehir hasn't been identified exactly. Even though the date of the Karacaşehir village can be reduced to the $15 \mathrm{Th}$ century according to the historical archives, there is no architectural data to verify this. Therefore we can say that Today's Karacaşehir settlement is reemerged in 1843 by placement of Karakeçili tribe and the Karacaşehir Mosque was rebuilt in 19th century instead of the ruined one.
\end{abstract}

Keywords: Karacasehir, Mosque, Eskisehir, Ottoman, Karacahisar 


\section{Giriş}

Son yıllarda Osmanlı imparatorluğunun kuruluşunun temelinin nerede atıldığı sorusuna geleneksel olarak kabul edilen Söğüt dışında da cevaplar aramaktadır. Özellikle Eskişehir'in merkezine çok yakın bir noktada yer alan Karacahisar Kalesinin Osman Gazinin ilk fethettiği yer olması sebebiyle bu anlamda önemi giderek artmışır ${ }^{1}$. Erken Osmanlı arkeolojisinin öne çıkan merkezlerinden birisi olan kalenin, Osmanlı'nın devlet olarak ortaya çıkmasında önemli bir rolü olduğu ve kimi yayınlarda Osmanlı'nın ilk başkenti olarak adlandırıldığg görülmektedir. ${ }^{2}$

Aşıkpaşazade, Neşri, Oruç Bey vb kroniklerde, Osmanlı payitahtının kurulduğu ve ilk hutbenin M. 1299 y1lında Dursun Fakıh tarafından Karacahisar'da okunduğ ${ }^{3}$ bilgisi verilmektedir. Buna göre ilk hutbenin okunduğu yerin alınan kale içinde bir cami/mescit olduğu fikri ilk akla gelendir. Ancak 1999-2014 yılları arasında yapılan kazı çalışmalarında henüz kalenin içinde yer alan, ibadet için kullanılabilecek bir mekâna rastlanmamıştır (Altınsapan- Palalı, 2018, s. 184). Dolayısıyla ilk hutbenin okunduğu yerin neresi olduğu henüz tam anlamıyla netleştirilememiştir. Cezmi Karasu ve Halime Doğru, kazı ve yüzey araştırmalarında kalede içinde bir caminin kalıntılarına rastlanmamasının sebebini, Karacahisar Kalesinin yakınındaki askeri bölge içinde kalan alanda bir başka yerleşimin olabileceği savıyla açıklamaktadırlar (Karasu vd., 2010, s. 66).

Kalenin fethinden itibaren kaynaklarda burası ile birlikte anılan Karacaşehir ve burada bulunan Karacaşehir Camisi hakkında henüz detaylı bir çalışma yapılmamıştır. Günümüzdeki Karacaşehir yerleşimine dair ilk bilgi 15. Yüzyılda iskân görmeye başladığıdır (İnalcık, 2006 s.11). Buna rağmen burada bulunan Karacaşehir Cami ilk hutbenin okunduğu yapı olarak kabul edilmektedir. Günümüzde yapılan hutbenin okunmasının yıldönümü kutlama faaliyetlerine kadar pek çok yerde ilk hutbenin okunduğu yapı olarak burası zikredilmektedir. Devlet arşivlerindeki 1890-1900 yıllarına ait bazı belgelerde yapının Sultan Osman Gazinin ilk hutbe okutturduğu yer olduğu belirtilmektedir. Karacaşehir Köyü Camisinin bahçesi içinde bulunan Kütahya Vakıflar Bölge Müdürlüğü tarafindan yerleştirilmiş levhada da M. 1299 tarihi ve Osmanlının ilk hutbesinin ${ }^{4}$ okunduğu yer olduğu bilgisi karşımıza çıkmaktadır (Fotoğraf 14). Ancak Osman Gazi'nin sultan olarak ortaya çıkışını simgeleyen hutbenin günümüzde ayakta olan bu yapıda $\mathrm{m}$ ? $\mathrm{Bu}$ yapının yerinde bulunan daha erken tarihli bir yapıda mı? Yoksa Kalenin içinde ya da yakınında bulunan başka bir yapıda mı okunduğu kesinleştirilememiştir.

Araştırmamızda öncelikle Karacaşehir yerleşiminin elimizdeki kaynaklardan yola çıkılarak bir tarihçesi oluşturulmuştur. Böylece bugün ayakta olan caminin hutbenin okunduğu yer olduğu sav1 sorgulanacak, kesin bir cevap verilemese de yapının bu şekilde kabul edilmesi fikrinin altında yatan sebepler tartışılacaktır. Henüz üzerinde yeterince araştırma yapılmamış Karacaşehir Camisi bilimsel araştırma yöntemleri ile incelenerek, restorasyon öncesi ve sonrası durumu belgelenecektir. Tüm

\footnotetext{
${ }^{1}$ Osman Gazi'nin ilk fethi olan Karacahisar'ın Osmanlı'nın kuruluş hutbesinin okunduğu yer olması dolayısıyla Devletin ilk başkenti olma özelliğini de taşıyabileceği Karasu vd. hazırladığı Osmangazi İlkler ve Karacahisar adlı yayında belirtilmiştir. (Karasu vd. 2010, s.60)

${ }^{2}$ Karacahisar'a Osmanlı beyliğinin başkenti olarak bakmak gerektiği fikri Osmanlı kroniklerinde anlatılanlarla da örtüşmektedir (Altısapan vd. 2015, 624).

${ }^{3}$ Aşıkpaşazade Karacahisar'ın Osman Gazi tarafından 1288 yılında ve Selçuklu Sultanı Alaaddin Keykubat'ın bilgisi dahilinde fethedildiğini anlatmaktadır. Osmanlı'nın bağımsız bir beylik olarak kurulması ise 1299 yılında Karacahisar'da Osman Gazi'nin adına hutbe okunması ile olmuştur (Yavuz-Saraç,2003., s.71-72).

${ }^{4}$ Kronikler Osman Bey adına okunan hutbenin ne zaman okunduğuna dair farklı bilgiler vermektedirler. Aşıkpaşazade 1299, Neşri 1299, Oruç Bey 1291 ve İbn-i Kemal 1289 tarihlerini vermektedirler. (AltınsapanPalali, 2018, 29).
} 
bunlardan yola çıkılarak yapıya dair sağlıklı bir değerlendirme ve bulunduğu bölgedeki benzer örneklerle bir karşılaştırılmasının yapılabilmesi çalışmamızın bir başka amacıdır.

\section{Karacaşehir Tarihçe}

Karacaşehir Köyü yerleşiminin tarihsel başlangıcını kesin olarak bilmiyoruz. Ancak Eskişehir ve etrafındaki bölge coğrafi konumu dolayısıyla insanoğlunun tarihi boyunca kesintisiz yerleşim görmüştür (İznik, 2003, s. 67). Kentin en erken tarihli yerleşim alanı günümüzde merkezin 3 kilometre doğusunda bulunan Dorylaion denilen bölgedir. Strabon'a göre kent adını Eretria'lı Doryleos'tan almaktadır (Altınsapan-Palalı, 2018, s. 17). Bu ad Helenistik, Roma ve Bizans dönemlerinde Dorilaion (Dorylaion, Dorileo, Doryleon, Dorylaeum) olarak süregelmiştir. Bizans döneminde kentte üç önemli yerleşim alanı karşımıza çıkmaktadır. Bunlar Dorylaion denilen bölge, buranın 3 kilometre batısında, günümüzde Hamamyolu olarak bilinen kaplıcalar bölgesi (Ilıca) ve kentin 11 kilometre kuzey batısında bulunan Karacahisar Kalesinin bulunduğu bölgedir. Karacahisar'ın Bizans'tan önceki dönemi ${ }^{5}$ ile ilgili kesin bilgilere sahip değiliz. Bizans döneminde ise Kütahya Eskişehir arasında yer alan Kayser kale ile haberleşmek için kullanıldığg bilinmektedir (Parman, 2003, s. 77). Kalede gerçekleştirilen kazı çalışmaları ve çıkan Bizans sikkeleri, kalenin 7-11. yüzyıl arasında iskan olduğunu ve bunun Geç Bizans'a kadar neredeyse kesintisiz olarak devam ettiğini göstermektedir (Altınsapan vd. 2015, s. 627). Osman Bey Sögüut’e yerleştikten sonra Karacahisar Tekfuru ile savaşmış onu yenerek 1288 yılında Karacahisar Kalesini almıştır.

Karacaşehir'deki ilk yerleşimin ise Karacahisar'ın Osmanlılar tarafından fethedilmesinden sonraki bir dönemde olduğu düşünülmektedir. Osmanlı kaynaklarında Karacahisar ve Karacaşehir'in adlarının zaman zaman bir biri yerine kullanıldığ görülmektedir. 1999'dan itibaren Kalede yapılan kazılar ve bilimsel araştırmalar sonucunda bu karmaşa çözülmeye başlamıştır ${ }^{6}$. Karacahisar Kalesinin önemli bir uç kalesi olduğu, 1299 yılında ilk hutbenin okutularak Osmanlı Beyliğinin kurulduğu ve ilk gümüş sikkenin bastırıldığı yer olduğu çeşitli kroniklerde belirtilmektedir ${ }^{7}$. Kaledeki kazı çalışmalarında çok sayıda Erken Osmanlı Dönemine tarihlendirilen sikkeler, ok uçları ve 16. Yüzyıla ait seramik buluntular ele geçirilmiştir. Âşıskpaşazâde, H. 699 (M. 1299-1300)'da Karacahisar'ın alınmasının ardından boş kalan evlere Osman Gazi tarafından Germiyan ülkesinden ve başka bölgelerden insanların yerleştirildiğini, şehrin güzelleştirildiğini, kiliselerin mescit ve cami yapıldığını anlattıktan sonra, Cuma hutbesinin Karacahisar'da, Bayram hutbesinin Eskişehir'de okunduğunu ve namazın burada kılındığını belirtmektedir (Yavuz-Saraç,2003, s.71-72). Metinden anlaşılacağı gibi hutbenin okunduğu yerin alınan kale içinde bir cami/mescit olduğu fikri ilk akla gelendir. Ancak 1999-2014 yılları arasında yapılan kazı çalışmalarında henüz Aşıkpaşazadenin bahsettiği kiliseden camiye

\footnotetext{
${ }^{5}$ Osmanlı Kroniklerinde Bizans kalesi olarak geçen yapının adının Melangeia olabileceği bazı araştırmacılarca düşünülmektedir (Ramsay,1890, s.28-Parman, 2003, s. 77).

${ }^{6}$ Karacahisar kalesi, Eskişehir'in $7 \mathrm{~km}$. güneybatısında, Porsuk çayının kenarında yükselen bir platonun üzerinde bulunmaktadır. Kale ile ilgili çalışmalar ilk kez 1999 yılında Prof. Dr. Halil İnalcık önderliğinde Anadolu Üniversitesi Edebiyat Fakültesi Arkeoloji, Sanat Tarihi ve Tarih Bölümlerinde görev yapan akademisyenler ve Prof. Dr. Halime Doğru Başkanlığında bir heyet ile başlatılımıştır. 2000-2001 yılında Prof. Dr. Ebru Parman danışmanlığında, Eskişehir Arkeoloji Müzesi başkanlığında temizlik ve çevre düzenlemesi çalışmaları yapılmıştır. 2002-2005 yılları arasında Prof. Dr. Ebru Parman başkanlığında Kültür Bakanlı̆̆ kazı çalışmaları yapılmıştır. 2009 yılında Eskişehir Arkeoloji Müzesi Müdürü Dursun Çağlar'ın başkanlığında çalışmalar yeniden başlatılmıştır. 2011-14 yılları arasındaki kazı çalışmalarını Prof. Dr. Erol Altınsapan ve Ekibi devam ettirmiştir (Altınsapan-Palalı, 2018, s. 14).

${ }^{7}$ Osmanlı kroniklerinde Osman Bey'in Karacahisar Kalesinde sikke bastırdığı yönünde bilgiler karşımıza çıkmasına rağmen Karacahisar kazılarında Osman Bey adına bir sikke bulunamamışır.
} 
çevrilen ya da ibadet için kullanıldığı düşünülen bir yapı tespit edilememiştir (Altınsapan-Palalı, 2018, s. 183). Kalenin surları dışında doğuda bir yerleşimin ya da pazar yerinin olabileceği, buraya Türklerin

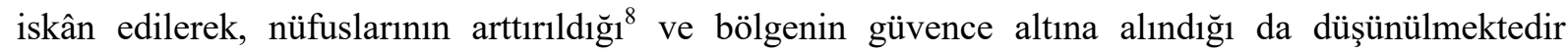
(Doğru, 2001, s. 115). Surların dışında olduğundan bahsedilen ve yukarı Karacaşehir denilen bu yerleşimin, kalenin etrafındaki alanda, günümüzdeki askeri bölgeyi de içine alan yerde olması muhtemeldir (Karasu vd, 2010, s. 66).

Günümüzdeki Kalenin eteklerinde bulunan Karacaşehir yerleşimine dair en sağlıklı bilgi Halil İnalcık'ın ortaya çıkardığı Osmanlı arşivindeki Maliyeden Müdevver (MAD) no. 18333 Sultanönü Evkaf Defterinde karşımıza çıkmaktadır. Araştırmacı Karacaşehir hakkındaki kayıtta burasının yukarı Karacaşehir -doğrusu Karacahisar diye vurgulayarak- kalesindeki halkın Fatih zamanında aşağıya taşınması ile kurulduğundan bahsetmektedir (İnalcık, 2006 s.11). Zamanla su sorunu olan tepenin boşaltılarak, nüfusun yamacın eteğine indirildiği ve burada Karacaşehir'in yeniden yapılandırıldığ belirtilmiştir. Belgede Kale ve yukarı şehrin Fatih döneminde terk edildiği, şehrin aşağı taşındığı, Defterdar Hüssam Bey tarafından yaptırılan camide padişahın emri ile Cuma namazı kılınarak, hutbe okutulduğundan bahsedilmektedir. Aynı kayıtta 15. Yüzyılın ikinci yarısında kalede cami olarak kullanılan bir yapıya ihtiyaç duyulmadığı, Kalenin Fatih zamanında terk edildiği ve Kanuni zamanında harap halde olduğu belirtilmektedir (İnalcık, 2006, s. 10). Bugünkü Karacaşehir Köyünün Fatih zamanında biçimlendiği ve kaledeki yerleşimin tamamen buraya taşındığı bilgisi henüz kalede yapılan çalışmalar soruncunda elde edilen verilerle doğrulanmamıştır (Altınsapan vd., 2015, s. 630 ). Kanuni Sultan Süleyman döneminde düzenlenen tahrir defterlerinde Karacaşehir'de bir camiden bahsedilmekte ancak bu Eskişehir'deki camilerle karıştırılmaktadır (Doğru, 2001, s. 118). 16. Yüzyılın ortalarında Dernschwam Eskişehir'i ziyaret ettiğinde Karacaşehir'e de uğramış ve burada Türk nüfusun yanı sıra Ermenilerinde bulunduğundan bahsetmiştir (Parman, 200, s.81). Bu dönemde Eskişehir'de gayri müslim nüfus kaydı bulunmazken, Karacaşehir'de 30 hanelik Ermeni Cemaati kaydına rastlanmaktadır (Doğru, 2001, s. 120) Karacaşehir 19. Yüzyılın ikinci yarısından itibaren yeniden ilgi çekmeye başlamıştır. 1843 yılında Karakeçili aşiretinin bir bölümü buraya yerleştirilmiştir. Yerleşim yeri II. Abdülhamit'in önerisiyle Osmanlı devletinin kuruluşu ve ilk hutbenin okunduğu yer olarak ön plana çıkarılmıştır (Öcal, 1986, s. 86). Kurtuluş Savaşı sırasında Eskişehir'de kalan Fransız gazeteci Berthe Gaulis'in yazılarında Karacaşehir Köyü Camii ve halkından da bahsedilmektedir (Yılmaz-Yegin, 2018, s. 171). Savaş sırasında tahrip edilmiş olan bölge daha sonra yeniden canlandırılmıştır. Görüldüğü gibi Karacaşehir Köyü neredeyse 15. Yüzyıldan günümüze kadar kesintisiz devam eden bir yerleşim sürecine ev sahipliği yapmaya devam etmektedir.

\section{Karacaşehir Cami}

Karacaşehir, Eskişehir'in Odunpazarı ilçesine bağlı, merkeze yaklaşık 6 km. uzaklıkta bir köydür. Cami Karacaşehir Köyünün içinde yer aldığı eğimli arazinin üst noktasında bulunmaktadır (Fotoğraf 1). Yaklaşık bir metre yüksekliğinde duvarla çevrili bir bahçe içinde yer alan yapının batısında, bir şadırvan doğusunda bahçe kotunun altında kalacak şekilde yapılmış abdesthane ve tuvaletler yer almaktadır. Günümüzde faal olarak kullanılan yapı Eskişehir Kültür ve Tabiat Varlıkları Koruma Kurulunun 14.01.2000 tarihi ve 1058 sayılı kararı ile tescil edilmiştir. Aynı Kurul 2014 yılında Camide restorasyon yapılabilmesi için izin vermiştir. Yapıda Kütahya Vakıflar Bölge Müdürlüğü tarafından 2015-2019 yılları arasında büyük bir yenileme çalışması yaptırılmıştır. Bu çalışmalarda

\footnotetext{
${ }^{8}$ Karacaşehir'e yerleştirilen Türkler Oğuzların Kayı boyuna bağlı, Karakeçili olarak anılan Yörüklerdir (Öcal, 1986, s. 86). Kalenin ve yerleşimin adının kaynağının sadece bu bölgede kullanılan taşların rengi ile ilgili olmadığı, bu boyun adı ile de ilişkilendirilebileceğinin düşünülmesi gerekmektedir.
} 
önceki yıllarda bakımsız bir halde olan yapının, beden duvarları sağlamlaştırılmış, tavan, minber, mihrap, son cemaat yeri yenilenmiş, çevre düzenlemesi yapılmış ve yapıya bir müezzin mahfili eklenmiştir. Ayrıca daha önce son cemaat yerine ve minareye yakın olan şadırvan, yapının sağlamlaştııılması ve korunması açısından aynı yerin daha aşağısına taşınmıştır.

Karacaşehir Camii tek katlı, tek mekânlı, dikdörtgen planlıdır (Çizim 1). Yapı dıştan kırma çatı ile örtülü ve tek minarelidir. (Fotoğraf 2). Caminin kuzey cephesinde, beden duvarlarından daha içte tutulmuş bir son cemaat yeri bulunmaktadır. Sonradan eklendiğini ${ }^{9}$ bildiğimiz bu mekanda restorasyon öncesinde, ortada dikdörtgen bir giriş ve iki yanda büyük dikdörtgen camları çıtalarla küçük karelere dönüştürülmüş pencereler yer almaktaydı. (Fotoğraf 3). Yapının beden duvarlarından daha alçak tutulmuş ve üzeri kiremit kaplı bir çatı ile örtülmüş bu bölüm günümüzde ahşap direklerin taşıdığı düz ahşap tavanlı, camekânlı bir alana dönüştürülmüştür (Fotoğraf 4).

Yapının yan ve arka cephelerinde son derece sade bir düzenleme karşımıza çıkmaktadır. Doğu ve batı cephelerde güney cepheye daha yakın tutulmuş ikişer dikdörtgen, mazgal pencere yer almaktadır. (Fotoğraf 4) Aynı pencereler güney cephede mihrabın olduğu bölümün iki yanında simetrik olarak kullanılmıştır. Karacaşehir Caminin cepheleri altı düz ahşap çıtalarla kaplı geniş bir saçak ile sonlandırılmıştır. Yapının üzeri Marsilya tipi kiremitle kaplı kırma çatı ile örtülüdür. (Fotoğraf 2-3)

Yapının son cemaat yerinden, çift kanatlı dikdörtgen bir kapı ile ibadet mekânına girilmektedir. Bu cephede girişin iki yanında dikdörtgen pencereler bulunmaktadır. Bir basamakla geçilen girişin sağında ahşap bir merdivenle kadınlar mahfili olarak kullanılan yarım asma kata çıkılmaktadır (Fotoğraf 6). Bu merdivenlerin sağında minarenin kapısı yer almaktadır. Harimin yaklaşık üçte birlik bölümünü kaplayan mahfil, iki ahşap direk tarafından taşınmaktadır. Direkler üst katta da devam ettirilerek altta ve üstte basit üçlü açıklıklar oluşturmuş, düz ahşap korkuluklar yerleştirilmiştir (Fotoğraf 8). Giriş kapısının iki yanında bulunan pencereler kadınlar mahfili seviyesinde daha küçük olarak tekrarlanmıştır.

Camide harimin güney duvarındaki ana giriş ekseninde yarım daire, basık kemerli bir mihrap nişi yer almaktadır. Mihrap nişi yalın, dar bir silme ile çerçevelenerek vurgulanmıştır. İç mekân mihrabın iki yanında, doğu ve batı duvarlarda bulunan ikişer pencere ile aydınlatılmıştır. Harimin beton zemini turkuaz renkli halı ile kaplanmıştır. Mihrabın solunda bulunan eski minber son derece basit, çıtalarla oluşturulmuş üçgen formlarla süslenerek, piramidal külahla örtülmüştür (Fotoğraf 7). Mihrabın sağındaki yapı köşesinde de bir müezzin mahfili bulunmaktadır. Restorasyon sonrasında her iki öğede yapının bütününe uydurularak kahverengi ahşaptan yapılmıştır (Fotoğraf 10). Harim basit ahşap çıtaların yan yana dizilmesiyle oluşturulmuş bir tavan örtüsüne sahiptir. Bu örtünün mekânın tam ortasına gelen yerde kare formda çökertildiği ve dıştaki çıtaların tersi yönünde yerleştirilmiş çıtalarla buranın ayrıca vurgulandığı görülmektedir (Çizim 2-Fotoğraf 9). Bu basit çökertme örtü tavanda üst üste yeniden uygulanmaya devam ettirilse idi, Eskişehir'de ve ilçelerinde karşımıza çıkan çökertme tavanlı camilerin bir örneği oluşturulabilirdi.

Yapının en özgün verileri son cemaat yeri ile batı cephenin birleştiği köşede yer alan minarede karşımıza çıkmaktadır. Dikdörtgen kaideli minarenin papuç bölümünün üzerinde sade taş bir bilezik yer almaktadır. Tek şerefeli, silindirik gövdedeki en dikkat çekici süsleme detayı şerefe altında karşımıza çıkan testere dişi uygulamasıdır. (Fotoğraf 11). Buranın biraz altında burgulu taş bir bilezik yer almaktadır. Şerefe kapısında tuğlalar dikine yerleştirilerek sağır kemer oluşturulmuştur. Petekten

\footnotetext{
${ }^{9}$ Eskişehir Kültür ve Tabiat Varlıklarını Koruma Kurulundan alınan bilgilere göre, yapıda daha önce bulunan basit üç ahşap desteğin taşıdığı sundurma biçimindeki son cemaat yeri, 1990 yılında restorasyondan önceki haline dönüştürülmüştür. Şadırvan yapıya 1970 yılında eklenmiştir. Yapı hakkında her türlü bilgi ve belgeye ulaşmamız için desteğini esirgemeyen Eskişehir Kültür ve Tabiat Varlıklarını Koruma Kurulu çalışanlarına özellikle Sanat Tarihçisi Pınar AKIN'a çok teşekkür ederim
} 
külaha geçmeden önce altı adet dar mazgal pencere yerleştirilmiştir. Bu pencereler gövdenin ortasında ve kaideden gövdeye geçilen yerdeki düz bileziğin altında da görülmektedir. Peteği sonlandıran profilli taş silme üzerinde iki sıra taş ve üstünde tuğladan örülmüş küçük bir kubbemsi külah uygulaması dikkati çekmektedir. Minare bölümlerinin kendi içinde malzeme ve teknik açıdan farklı özellikler göstermesi yapının birkaç dönemi olduğunu göstermektedir. Minare alemi, uçları yukarı bakan bir hilalin ortasında çok kollu bir yıldız formundan oluşmuştur (Fotoğraf 11 ).

Caminin bahçesi içinde kuzey batı köşede yer alan şadırvan restorasyondan önce altıgen planlıyken, yenisi sekizgen bir şemaya sahiptir. Şadırvan merkezde yer alan sekizgen su deposu ve sekizgen zeminin her bir köşesine yerleştirilen ahşap direklerin taşıdığ kiremit kaplı kırma bir çatı ile örtülüdür (Fotoğraf 5).

Karacaşehir Cami kagir sistemde karışık derzli moloz taş duvar örgüsüne sahiptir. Yapının beden duvarlarında kimi kısımlarda kaba yonu taş ve tuğlanın birlikte kullanıldığı görülmüştür (Fotoğraf 12). Restorasyon çalışmalarında yapının güçlü bir temelinin bulunmadığı, dolayısıyla sık sık onarım geçirmek zorunda kaldığı ortaya çıkmıştır. Yapı duvarları içte ve dışta sıvalı ve boyalıdır. Harim tavanı, kadınlar mahfili, minber, müezzin kürsüsü, kapı ve pencerelerde ahşap malzeme kullanılmıştır. Yapının tüm cephelerindeki pencerelerde demir parmaklıklar bulunmaktadır. Minare kaidesinde araları derzlenmiş sarı renkli düzgün kesme taş, papuç bölümünde gri renkli düzgün kesme taş, minare gövdesi, şerefe ve petek kısmında araları beyaz harç dolgulu tuğla örgü sistemi kullanılmıştır. Minare külahı iki sıra kaba yonu taş, iki sıra tuğla örgüden sonra sıvalı bir bölümden oluşmaktadır. Şadırvanda su deposu ve etrafında beyaz mermer kullanılmıştır.

\section{Değerlendirme}

Çalışmamızın konusu olan Karacaşehir Camii Osmanlı Devletinin kuruluşunun merkezi olan Karacahisar Kalesi ile ayrılmaz bir şekilde ilişkilendirilmiştir ${ }^{10}$. Kalenin fethinden itibaren burası, bugünkü askeri bölge içinde kaldığını bildiğimiz kale dışı yerleşimi ve günümüzdeki Karacaşehir Köyü kaynaklarda iç içe geçmiştir. Hatta zaman zaman kaynaklarda Eskişehir ve Karacaşehir'in aynı yermiş̧ gibi adlandırıldığı da görülmektedir (Doğru, 200, s.121). Dolayısıyla günümüzdeki Karacaşehir Camisinin tarihlendirilmesinde bir karmaşa sorunu vardır.

Yapının restorasyondan önce üzerinde bulunan metal levhada belirtilen, M. 1299 inşa tarihinin doğru olması muhtemel değildir ${ }^{11}$. Karacahisar Osman Gazi tarafından M. 1288 yılında Selçuklu Sultanı Alaaddin Keykubat'ın tahtta olduğu sirada fethedilmiştir (Altınsapan vd.2015, s. 623) Fetih'in ardından bölge halkı Eskişehir'e gelerek Şeyh Edebali'ye hutbe okutmak istediklerini bildirmiştir. Dursun Fakih'in Karacaşehir'e hatip tayin edilerek hutbeyi okuduğu ve Osman Bey'in şehirde cemaatle Cuma namazını kılmaya icazet verdiği pek çok kaynakta vurgulanmıştır (Yavuz- Saraç, 2003, s. 72). Ancak hutbenin okunduğu yer konusu netlik kazanmamıştır. Dursun Fakih'in ilk hutbeyi okunduğu caminin neresi olduğu kaynaklarda yeterince açık değildir (Doğru, 2001, s.121). Kalenin Fatih Dönemi'nde yayınlanan bir fermanla birlikte boşaltıldığ 1 ve halkın bugün Karacaşehir olarak

10 Bunun güzel örnekleri Devlet arşivlerindeki Osmanlı belgelerinde karşımıza çıkmaktadır. Belgelerde Karacaşehir kaza olarak tanımlanırken Çalışmamızın konusu olan yapı Osman Gazi'nin ilk hutbesini okuttuğu Karacahisar mevkiinde inşa edilen cami olarak tanımlanmaktadır. Ancak bu belgelerin tarih aralığı H. 13081323/ M. 1890/1906 olarak karşımıza çıkmaktadır. Bu tarihlerde kalede yoğun olmasa da yerleşimin devam ettiği Karacahisar kazısında ele geçirilen 17. 19. Yüzyıla tarihlenen tütün lülelerinden anlaşılmaktadır (Altınsapan-Palalı, 2018, s. 184). Devlet arşivlerinde karşımıza çıkan belgelerde ise Karacaşehir'de 19. Yüzyıl sonunda Türkler ve Ermeni nüfustan oluşan yoğun bir yerleşimin olduğunu göstermektedir.

${ }^{11}$ Yapının günümüze gelebilmiş bir kitabesi bulunmamaktadır. Günümüzde yapının bahçesi içinde bulunan bilgi levhasında da M. 1299 tarihi karşımıza çıkmaktadır. 
bilinen alana taşındığı yönünde bilgiler olmasına rağmen, (Doğru, 1992, s.16; Doğru, 2001b, s.223) kazı çalışılmalarında ele geçen buluntuların ışığında, Kaledeki yerleşimin 14.yüzyıldan 18. yüzyıla kadar kesintisiz devam ettiği düşünülmektedir (Altınsapan vd. 2015: 630 ). Ayrıca Karacaşehir Köyünün II. Abdülhamit döneminde yeniden canlandırılması ve yapılara bu dönemde yapılan müdahalelerinde tarihlendirme yapılırken göz önüne alınmas1 gerekmektedir.

Günümüzde ayakta olan yapının en sağlıklı tarihlendirilmesi Devlet Arşivlerindeki belgelerden yola çıkılarak yapılabilir. Osmanlı Y.,PRK.UM.18-37 H. 1308/ M. 1890 tarihli belgede Osman Gazi'nin ilk hutbesini okuttuğu Karacahisar mevkiinde inşa edilen camide merasim yapıldığı bilgisi verilmiştir. DH.MKT.2420-68 H. 1318/ M. 1900 tasnif nolu belgede ise Sultan Osman Gazi'nin ilk hutbe okutturduğu Eskişehir civarında Karacahisar karyesindeki caminin yeniden inşası sebebiyle tören yapıldığından bahsedilmektedir. Belgelerden 19. yüzyılın sonunda burada bir yapının olduğunu ama yıkıldığını ve bugünkü yapının yıkılan caminin yerine H. 1318 /M. 1900 yılında inşa edildiğini öğreniyoruz. Bu bilgiler ışığında yapı ile ilgili bu tarihlerin arkeolojik verilerle de kanıtlanması ancak kalede devam eden kazıların ilerlemesi ve çalışma alanlarının önce kale etrafına, daha sonra da Karacaşehir Köyüne genişletilmesi ile mümkün olabilir.

Karacaşehir Camisinin oldukça küçük ölçekli, yalın ve süslemesiz bir anlayışla inşa edilmiş olması yapı ile ilgili sorulara çözüm bulunamamasının bir diğer sebebidir. Karşılaştırma yapabileceğimiz çok az mimari veriye sahibiz. Yapının Sanat Tarihi açısından en önemli özelliği ahşap tavanlı ve ahşap destekli cami geleneğinde bir örnek olmasıdır. Türk mimarisinde köklü geleneği olan bu yapı tipi Selçuklular ve Osmanlılar zamanında da farklı boyutlarda örneklerle inşa edilmeye devam edilmiştir. Karacaşehir Camii düz ahşap tavanlı camiler içinde, tavanın ortasına gelen bölümün kare şeklinde tavan yüzeyinden derince içeri çekilmesi ile farklılaştırılmış bir uygulamadır ${ }^{12}$. Çökertme tavanlar Eskişehir ve civarındaki cami ve mescitlerde karşımıza oldukça çok çıkmaktadır. Bu tekniğin Selçuklulardan beri (günümüze gelen bir örnek olmamasına rağmen) bilindiği düşünülmektedir. Ahşap malzemeli bindirme tavanlar Anadolu'da en erken tarihli Bilecik Osmaneli İlçesi Rüstem Paşa Camii, Kastamonu Ferhat Paşa Camii, Kastamonu Hasan Efendi Camii gibi 16. yüzyıl örneklerinde karşımıza çıkmaktadır. Bu teknik Anadolu'nun pek çok bölgesinde 19. ve 20. Yüzyıl başlarına kadar kullanılmıştır (Altınsapan,-Parla, 2004, s:384-388). Karacahisar Camisinde bu uygulama, harimin ortasına gelen bölümde tavanın bir kez kare biçiminde çökertilmesi şeklinde kullanılmıştır. Eskişehir Dağküplü Köyü Camisinde ise tavanın tamamını kaplayan bir baklava dilimi biçiminde uygulanmıştır. Gürleyik Köyü Aşağı Mahalle Camisinde bu iki yapının tavan çökertmesinin (Çizim 5) birlikte kullanıldığından bahsedebiliriz (Altınsapan-Parla, 2004 s. 391-392). Eğer günümüzdeki Karacaşehir Camisi kaynaklarda verilmeye çalışıldığı gibi 16. Yüzyıla kesin olarak tarihlendirilebilseydi, Eskişehir'de ve ilçelerinde karşımıza çıkan çökertme tavaların bir ön örneği olabilirdi. Oysa 1902 yılında inşa edilen Dağküplü Köyü Camii tavanı 1960 yılında köy halkı tarafından değiştirilerek bugünkü halini almıştır (Altınsapan- Parla, 2004, s. 168). Bu da Karacaşehir Camisi verilerinin bize çoğunlukla 19 yüzyıl ve daha geç tarihleri verdiğini göstermektedir.

Karacaşehir Camisinin en özgün mimari verisi, şerefenin üst bölümünün Kurtuluş Savaşı sırasında yıkıldığı ve bu bölümün daha sonra tamir edildiği bilinse de minaresidir. Yapının minaresi geleneksel olarak kuzeybatı köşeye bitişik ve kaide üzerinde yükseltilerek inşa edilmiştir. Yapı dikdörtgenler prizması bir kürsü, köşeler pahlanarak geçilen pabuçluk, silindirik gövde, testere dişinin yer aldığ1 şerefe altı, silindir petek ve kubbemsi bir külahla biten bir minareye sahiptir ${ }^{13}$. (Ödekan, 1988, s. 526).

\footnotetext{
${ }^{12}$ Düz tavanlı câmiler de kendi içerisinde yine örtü sistemine göre; Düz göbeksiz tavanlı, düz çökertme tekne göbekli tavanlı, düz çıtalama göbekli tavanlı, düz -kubbeli tavanlı, düz tonozlu tavanlı ve düz- kademeli tavanlı câmiler şeklinde alt başlıklarla tanımlanmışlardır (Çevrimli, 2017, 198).

${ }^{13}$ Selçuk ve Erken Osmanlı Mimarlığında bölümlerden biri, örneğin kürsü ve pabuç, olmayabiliyordu (Ödekan, 1988, s. 526).
} 
Eskişehir'de özellikle geleneksel Osmanlı kent dokusunun merkezi olan Odunpazarı ve civarında çok sayıda tek şerefesi olan, altta taş kaide, üzerinde tuğla gövde ve şerefe altında tuğlaların farklı yerleştirilmesi ile oluşturulmuş kirpi saçak uygulaması formunda minareler karşımıza çıkmaktadır. Alaaddin Camii, Akarbaşı Camii, Orta Işık Camii, Müftü Camii, Tiryakizade Süleyman Ağa Camii ve Karapınar Camilerinin minareleri dikdörtgen kaide üzerinde silindirik gövdeli ve şerefe altı beş sıra kirpi saçaklı süslemeden oluşan örneklerden bazılarıdır. Bu örneklerin pek çoğunda minare sivri külah ile sonlanırken, Alaaddin Cami ve Eskişehir Mahmudiye Hara Camilerinde minare Karacaşehir Camii gibi kubbemsi külah ile sonlanmıştır (Fotoğraf 15-16). Erken Osmanlı Dönemi minareleri genel karakter olarak Selçuklu minare geleneğini devam ettirmişlerdir. Ancak Selçukluların camiyle oran ilişkisi gözetilmeden yapılmıs, anıtsal minarelerinin yerini, daha mütevazı ve yapının siluetiyle orantılı, küçük ölçekli ve sade minareler almıştır. Türk Mimarisinde Karahanlılardan Osmanlılara kadar kesintisiz bir şekilde süre gelen silindirik gövdeli minare formu bizim yapımızda da karşımıza çıkmaktadır. Anadolu Selçuklularında yaygın olarak kullanılan dikdörtgen prizma kaide; Osmanlılarda daha az tercih edilmiş ve özellikle Orhan Gazi döneminde kullanılmıştır (Uysal, 1990, s. 517). Eskişehir minareleri içinde Karacaşehir Camii minaresine en benzer örnekler Hara Camii ve Odunpazarı'ndaki şerefe altı kirpi saçaklı örneklerdir. Bu da bize yapının minaresinin yine 19. yüzyıl ve daha geç bir dönemi verdiğini göstermektedir.

\section{Sonuç}

Karacaşehir Camii çalışması kapsamında elde edilen bulgular ışığında, yapının tarihlendirilmesine dair elimizdeki kaynaklardan bir sonuç çıkarılabilir. Ancak yapıda 2015 den beri devam eden yenileme çalışmalarında zemin etüdü ya da duvarların onarılması sırasında yapının tarihlendirilmesine yardımcı olabilecek bir veri paylaşılmamıştır. Elimizdekilerden çoğunlukla 19 yüzyıl ve daha geç bir döneme tarihlendirebileceğimiz bu yapının, M. 1299'da Osmanlı'da ilk hutbenin okunduğu cami olamayacağı görülmektedir. Yapı mimari özellikleri açısından da bu kadar erken bir tarihte inşa edilmiş olabileceğini düşündürmemektedir. Ama yine de Karacaşehir Camisinin koruma grubu, Kültür ve Turizm Bakanlığı, Eskişehir Kültür Varlıklarını Koruma Bölge Kurulu 23.06.2014 tarih ve 2579 sayılı kararıyla "I. grup" olarak belirlenmiştir. Çünkü Osmanlı devletinin kuruluşu sürecinin merkezinde bulunan bu yapı, toplumsal bellek için önemli bir yere ve öneme sahiptir.

Türkiye'de özellikle son yirmi yılda muhafazakârlaşmanın giderek güçlenmesi, geçmişe dair önemli olayların anısının hep canlı tutulması anlayışını da beraberinde getirmiştir. Karacaşehir Camisi 'de tarihinden çok daha öncesi ritüeller ile kolayca ilişkilendirilmiş, yapıya yeni bir anlam oluşturulmuştur. ${ }^{14}$ Aslında bu Sanat Tarihi disiplininde yapıların korunmasına dair yeni bir bakış açısının göz ardı edilmemesi gerektiğinin altını çizmektedir. Bir yapının korunması için tarihçesi dışında kimi kıstaslarında bulunabileceğini hatırlatmaktadır. Kimi yapılar toplumsal bellek için oldukça önemlidirler. Çoğunlukla "Bir toplumda, bir toplulukta eskiden kalmış olmaları dolayısıyla saygın tutulup kuşaktan kuşağa iletilen, yaptırım gücü olan kültürel kalıntılar, alışkanlıklar, bilgi, töre ve davranışlar, anane": ${ }^{15}$ olarak tanımlanan gelenek kavramı aslında Anthony Giddens'a göre 19. Yüzyılda ortaya çıkmıştır (Gidens, 2000, s. 51). Bugün geleneksel olarak tanımladığımız bilgilerin çoğu aslında bu yüzyıldaki tarihselcilik anlayışı ile birlikte oluşturulmuştur. Dolayısıyla uluslar kendi tarihlerini kurgularken geçmişteki önemli olayları belirli yerlere ve bölgelere mâl etmişlerdir. Anthony Giddens'ın icat edilmiş olarak tanımladığı (Giddens, 2000, 52) bu gelenek örnekleri içinde

\footnotetext{
${ }^{14}$ Yapıya gelenek açısından yaklaşmam konusunda beni yönlendiren Anadolu Üniversitesi, Edebiyat Fakültesi Türk Dili ve Edebiyatı Bölümünden Doç. Dr. Çiğdem KARA'ya çok teşekkür ederim.

${ }^{15}$ http://sozluk.gov.tr/
} 
çalışmamızın konusu olan yapı da sayılabilir. Osmanlı Devletinin temelinin atıldığg bölgede bulunan Söğ̈̈t ve Karacahisar için de böyle bir gelenek ortaya çıkmıştır.

Erken Osmanlı dönemine ait bir belleğin günümüzde Karacaşehir Camii etrafinda çeşitli etkinliklerle beslenmesi, bize yapı için aslında kendi tarihi ile örtüşmeyen bir geleneğin yaratıldığını göstermektedir. $\mathrm{Bu}$ nedenle Karacaşehir günümüzde tarihi açıdan popüler bir yerleşime dönüşmüştür. Hatta Osmanlı devletinin kuruluşunun kaynağı olan Karacahisar'ın da tanınırlık açısından önüne geçmiştir. 


\section{Kaynakça}

Altınsapan, E., Palalı M. (2018). Osmanlı Beyliğinin Kurulduğu Yer Eskişehir Karacahisar Kalesi Kazı Buluntuları (2011-2014). İstanbul: Doğu Kütüphanesi.

Altınsapan, E. Gökalp Z., Yılmazyaşar H., ve Gerengi A. (2015) “2011-2014 Kazıları 1şığında Eskişehir Karacahisar Kalesi”, Akademik Sosyal Araştırmalar Dergisi, 3 (10), 621-633.

Altınsapan, E., (2014) “Karacahisar Kalesi Kazısı”, Eskişehir Rehberi, Eskişehir: Eskişehir Valiliği.

Altınsapan, E. (2005) “19. Yüzyıl Eskişehir Kent Dokusundan Günümüze Akarbaşı Camii”, ETO, Eskişehir Ticaret Odası yı1 22 Sayı: 95,s:62-65.

Altınsapan, E. Parla, C. (2004) Eskişehir Selçuklu ve Osmanlı Yapıları I, Anadolu Üniversitesi Yayınları No: 1548, Eskişehir.

Çetin, İ. (1996) “Tursun Fakı Hayatı ve Eserleri”, Türk Kültürü ve Hacı Bektaşi Veli Dergisi, Sayı 3

Çevrimli N. (2017) "Denizli ve Çevresinde Yer Alan Bazı Camilerin Yapı Elemanlarının Değerlendirilmesi”, Vakıflar Dergisi, 47, 169-204.

Çöl, N. (2005) "Eskişehir Kentinin oluşumu ve Tarih İçindeki Gelişimi”, ETO, Eskişehir Ticaret Odas1, Y11 22, Say1 96 s: 51-53

Darkot, B. "Eskişehir” İslam Ansiklopedisi, C.4, s: 384-387.1948

Doğru, H. (2011) “Osmanlı Devletinin Kuruluş Döneminde Eskişehir”, Eskiyeni, T. C. Eskişehir Valiliği Aylık Şehir Kültürü Dergisi Y11 2 Sayı: 23 s: 6-9 Eskişehir.

Doğru, H. (2000) Osman Bey'in İlk Fethi Karacahisar Kalesi, Anadolu Üniversitesi Araştırma Fonu Projesi No: 990824 (Proje Yürütücüsü: Halime Doğru)

Doğru, H. (2003) "Mahruse-i Sultanyüki’nden Eskişehir'e”, Kebikeç, 15, 49-63. Ankara: Sanat Kitabevi.

Doğru, H. (2001)“Karacahisar Kalesi ve Osmanlı Devletinin Kuruluşundaki Önemi” Anadolu Üniversitesi Sosyal Bilimler Dergisi, s: 105-127 Eskişehir.

Doğru, H. XVI. Yüzyılda Eskişehir ve Sultanönü Sancă̆g, İstanbul:Afa Yayınları.

Gel, M. (2009) “Kuruluş Devri Osmanlı “Fak1” Zümresinin Tipik Bir Öncüsü: Tursun Fakı” Ankara Üniversitesi Osmanlı Tarihi Araştırma ve Uygulama Merkezi Dergisi, sayı 26 s: 93-116

Giddens, A. (2000), Elimizden Kaçıp Giden Dünya, ( Çeviren: Osman Akınhay), İstanbul: Alfa Basım Yayım.

Gürsoy, E.,(2017) “Uşak İli Sivaslı İlçesi Akarca Köyü Camisi”, Elektronik Sosyal Bilimler Dergisi Cilt 16, Say1 62 s:1001-1014

İnalcık, H. (2006) "Karacaşehir Üzerine Bir Belge", VIII. Uluslararası Türkiye'nin Sosyal ve Ekonomik Tarihi Kongresi, Bursa: Lulu pres s:9 -12

İznik, E. (2003) "Eskiçağda Sessiz Bir Anadolu Kenti: Dorylaeum”, Kebikeç, 15, s: 65-76. Ankara: Sanat Kitabevi.

Karasu, C. Sakarya, T. Ve Berber, O. (2010) Osmangazi Illkler ve Karacahisar, Odunpazarı Belediyesi Kültür Yayınları -24

Kılıç, L. (1997) Anılarla Eskişehir, Eskişehir Rotary Kulübü. 
Öcal, Sefa, (1987) Devlet Kuran Kahramanlar, Türk Dünyası Araştırmaları Vakfı,

Ödekan, A. (1988) "Minareler (Biçimsel Analiz)." Mimarbaşı Koca Sinan: Yaşadığı Çă̆ ve Eserleri, 1: 525-529.

Parla, C. ,E. Altınsapan. (2004) Eskişsehir Selçuklu ve Osmanlı Yapıları I, Eskişehir: T.C. Anadolu Üniversitesi Yayınları.

Parman, E. (2003) "Eskişehir-Karacaşehir Köyünde Karacahisar Kalesi”, Kebikeç, 15, s: 77-83. Ankara: Sanat Kitabevi.

Ramsay, W. (1890) The Historical Geography of Asia Minor, London.

Sarıöz, P.(1998) Bir Zamanlar Eskişehir, Esbank, İstanbul 1998.

Uysal, A. O. (1990) Anadolu Selçuklularından Erken Osmanlı Dönemine Minare Biçimindeki Gelişmeleri, Ankara Üniversitesi Dil Tarih Coğrafya Fakültesi Dergisi, Cilt 33 say1 1-2, s: 505-533

Yavuz, K.ve Saraç, Y. (2003) Aşılkpaşazade Osmanoğullarının Tarihi, İstanbul: Koç Kültür Sanat Tanitim.

Yılmaz, A.-Yetgin, D. (2018) “Seyyahların Anlatımı İle Osmanlı'nın Son 30 Yılındaki Eskişehir (1892-1922)", Akademik İncelemeler Dergisi, 13/2: 159-182 http://dergipark.gov.tr/download/articlefile/540442

https://www.eskisehir.net/haber/gundem/eskisehir/osmanlinin-ilk-hutbesinin-okundugu-caminin-icleracisi-hali- ) (Erişim Tarihi 02/03/2019)

Eskişehir İli Karacaşehir Camii Revize Restorasyon Projesi Raporu

Kültürel Varlıkları Koruma Envanteri- Eskişehir Kültür Varlıklarını Koruma Kurulu

Arşiv Belgeleri

Osmanl1 Y..PRK.UM.18-37 H.1308 (1890)

Osmanl1 Y..PRK.UM. 77-37 H.1323 (1905)

Osmanl1 Y..PRK.AZJ. 51-13 H.1323 (1905)

Osmanlı DH. MKT.2420-68. H. 1318 (1900). 


\section{Fotoğraflar ve Çizimler}

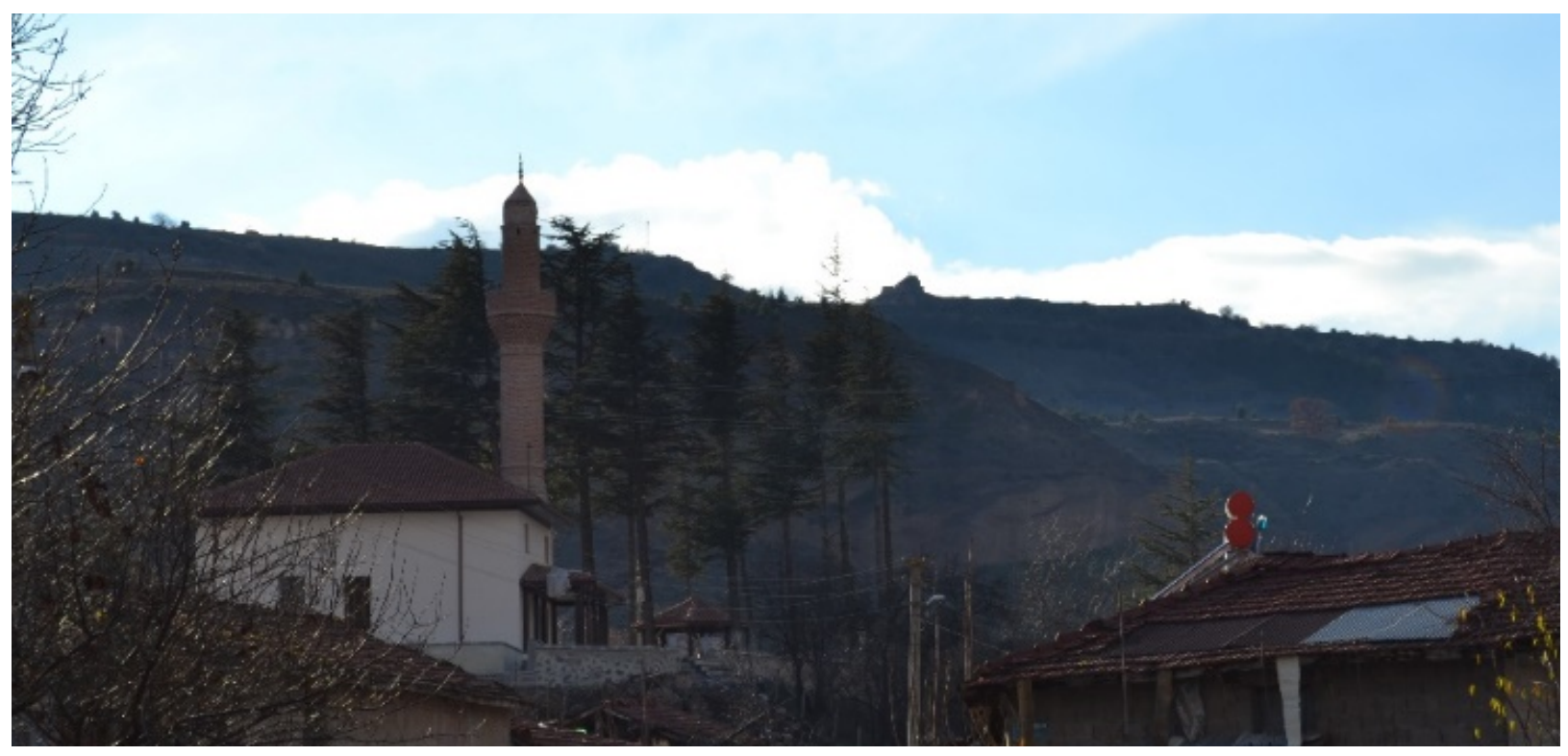

Fotoğraf 1- Karacaşehir Camisi ve arkasında Karacahisar Kalesi

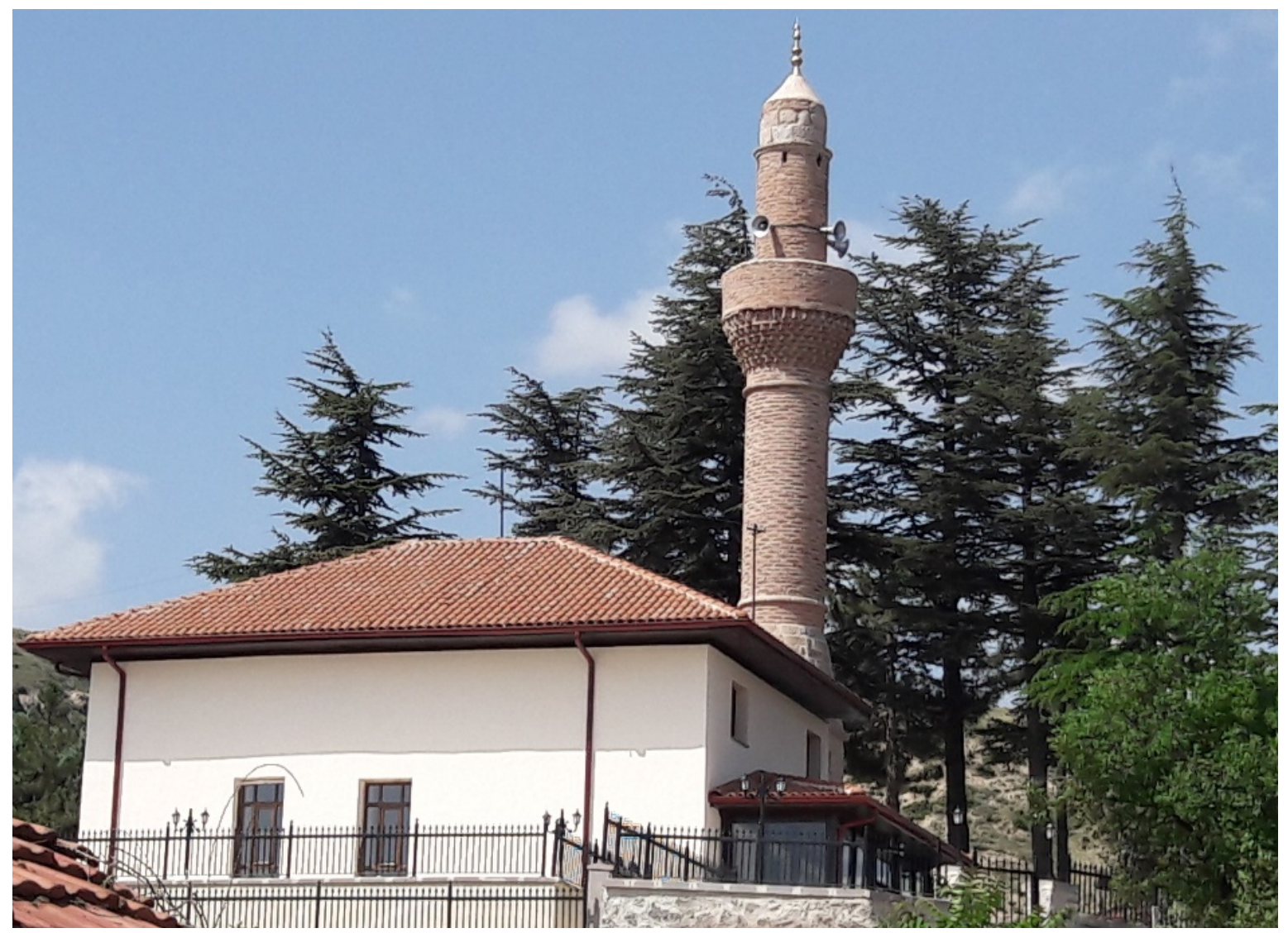

Fotoğraf 2- Karacaşehir Camisi 


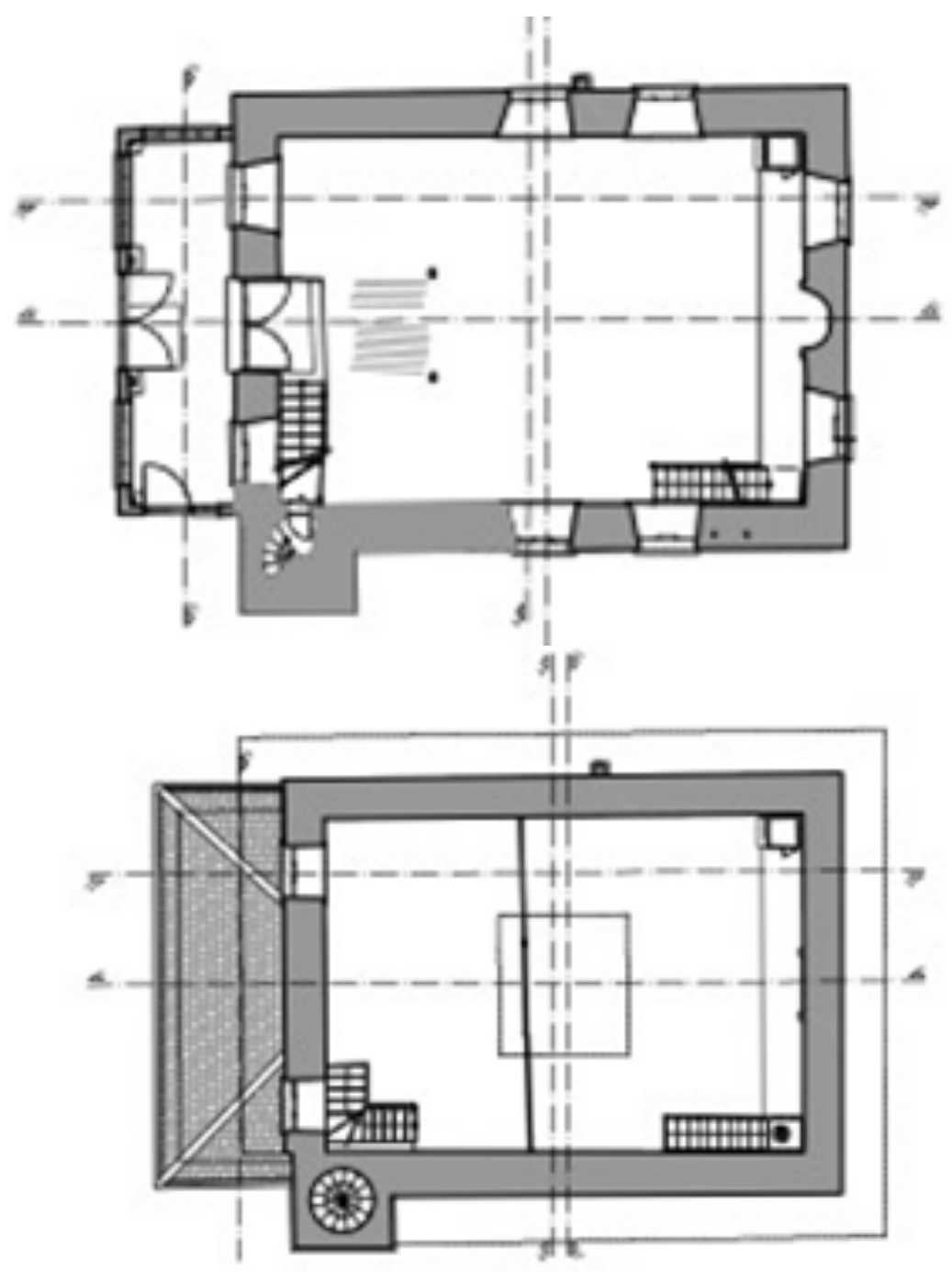

Çizim 1-Karacaşehir Camisi plan (Eskişehir Kültür ve Tabiat Varlıkları Müdürlüğü Arşivi)

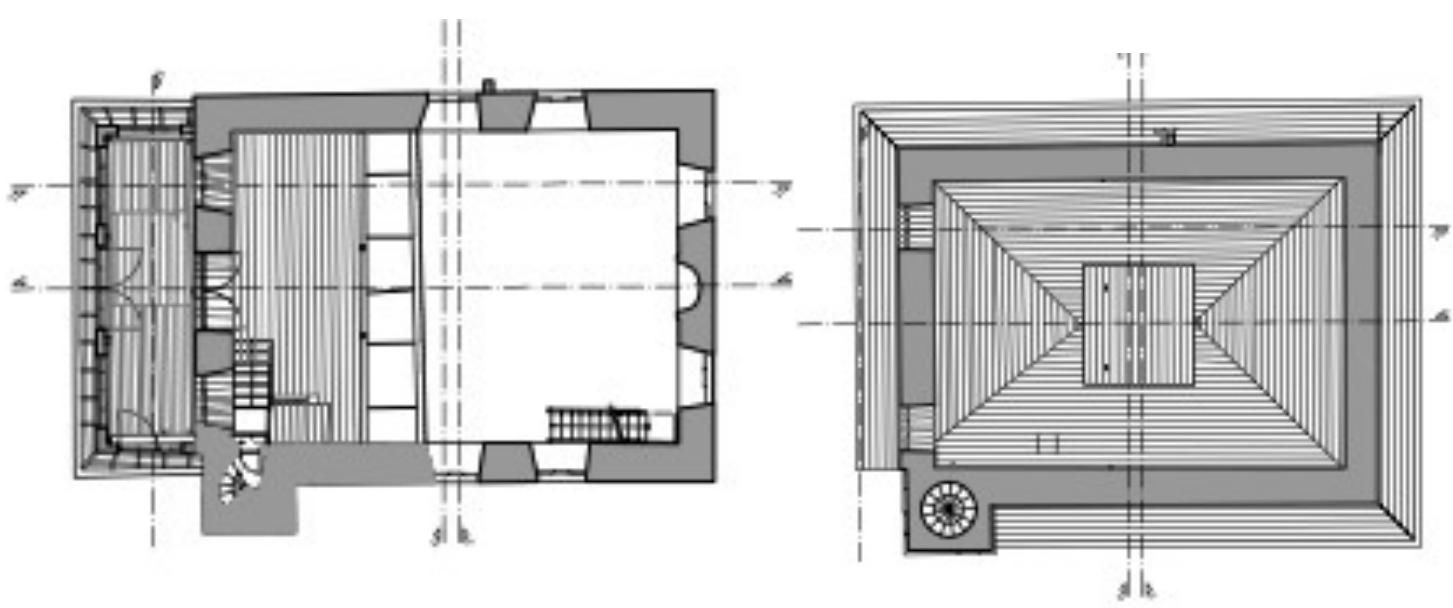

Çizim 2-Karacaşehir Camisi kadınlar mahfili ve tavan plan (Eskişehir Kültür ve Tabiat Varlıkları Müdürlüğü Arşivi) 


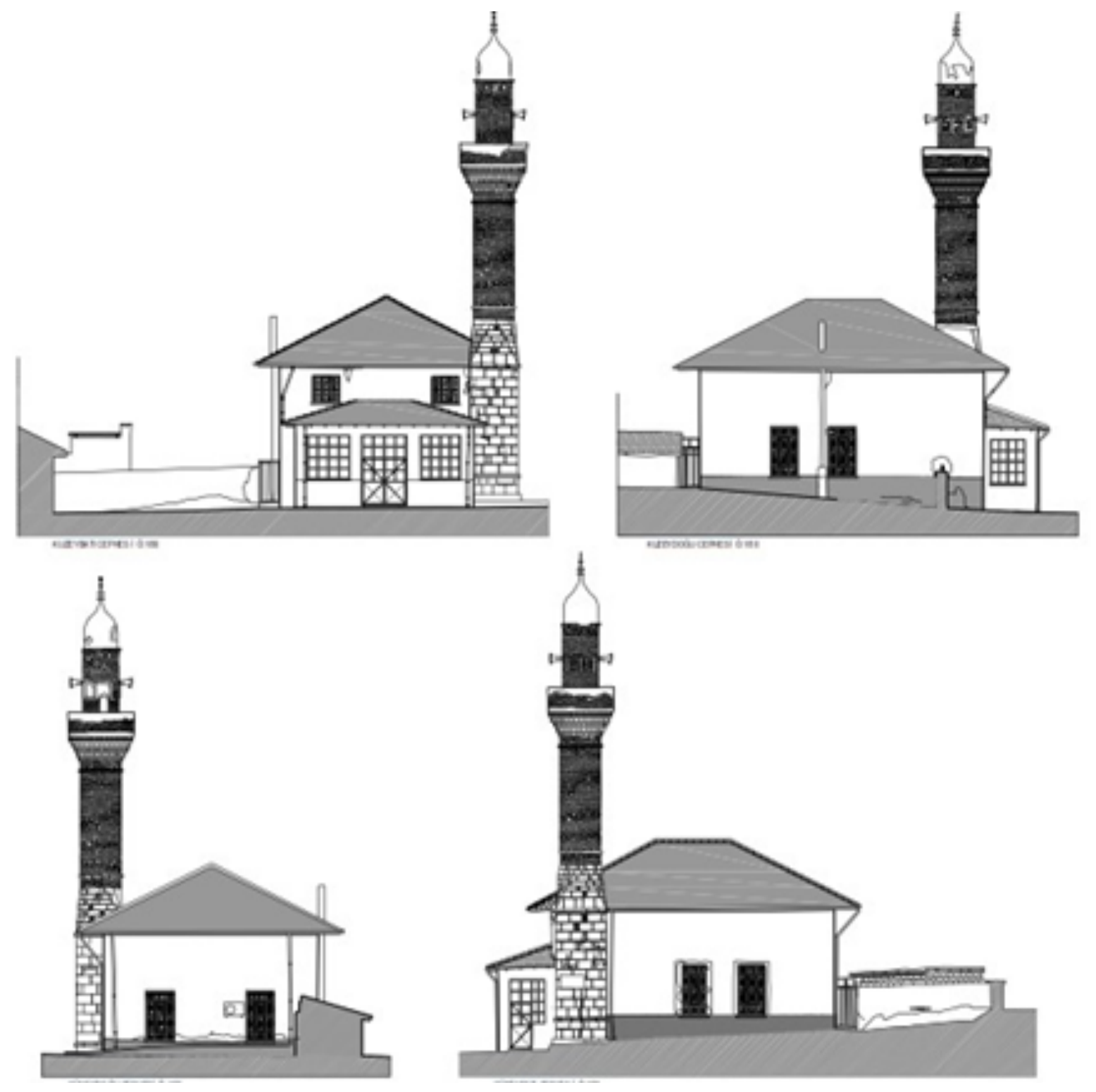

Çizim 3-Karacaşehir Camisi cephe çizimleri (Eskişehir Kültür ve Tabiat Varlıkları Müdürlüğü Arşivi) 

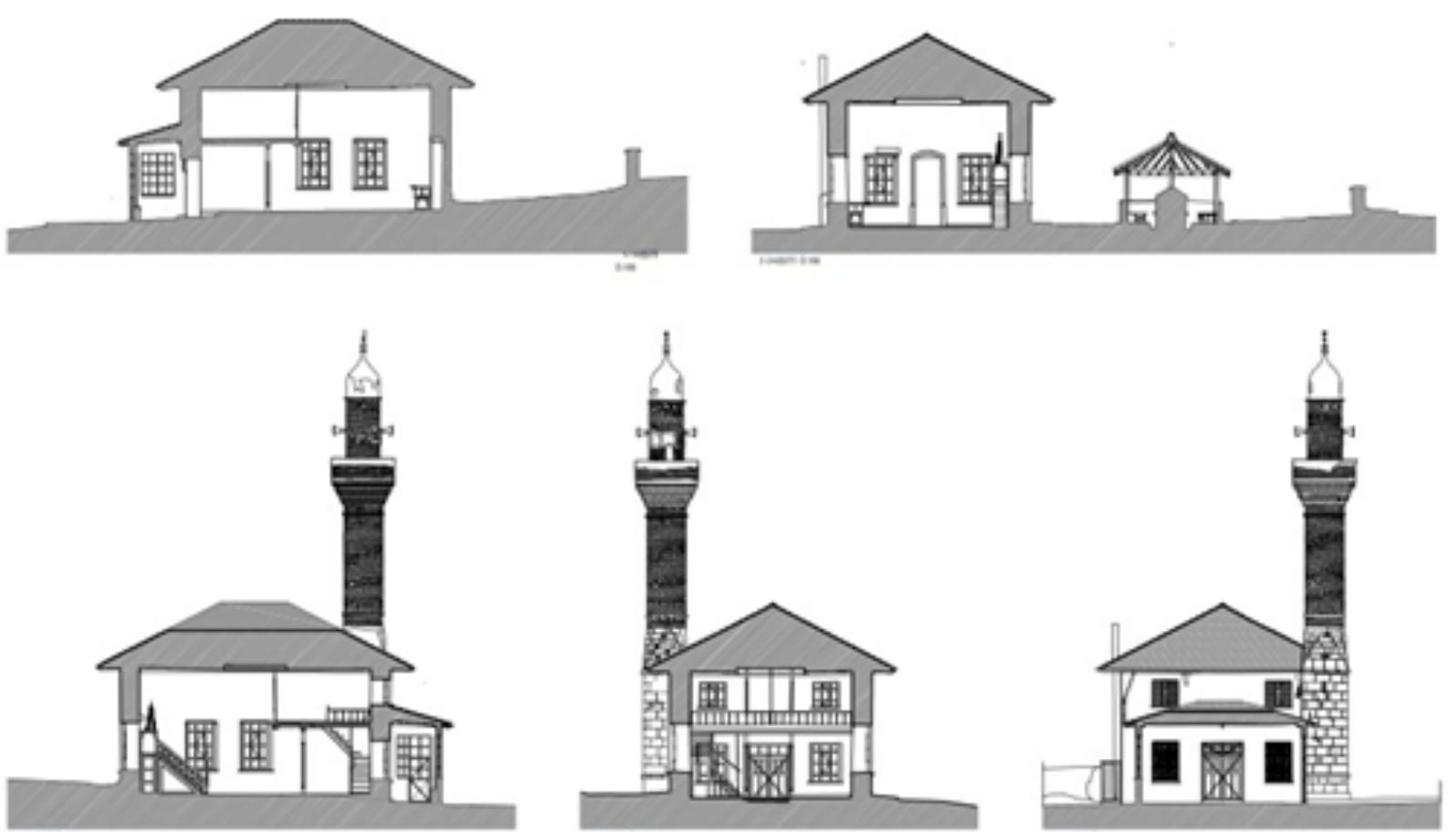

Çizim 4-Karacaşehir Camisi kesitleri (Eskişehir Kültür ve Tabiat Varlıkları Müdürlüğü Arşivi)

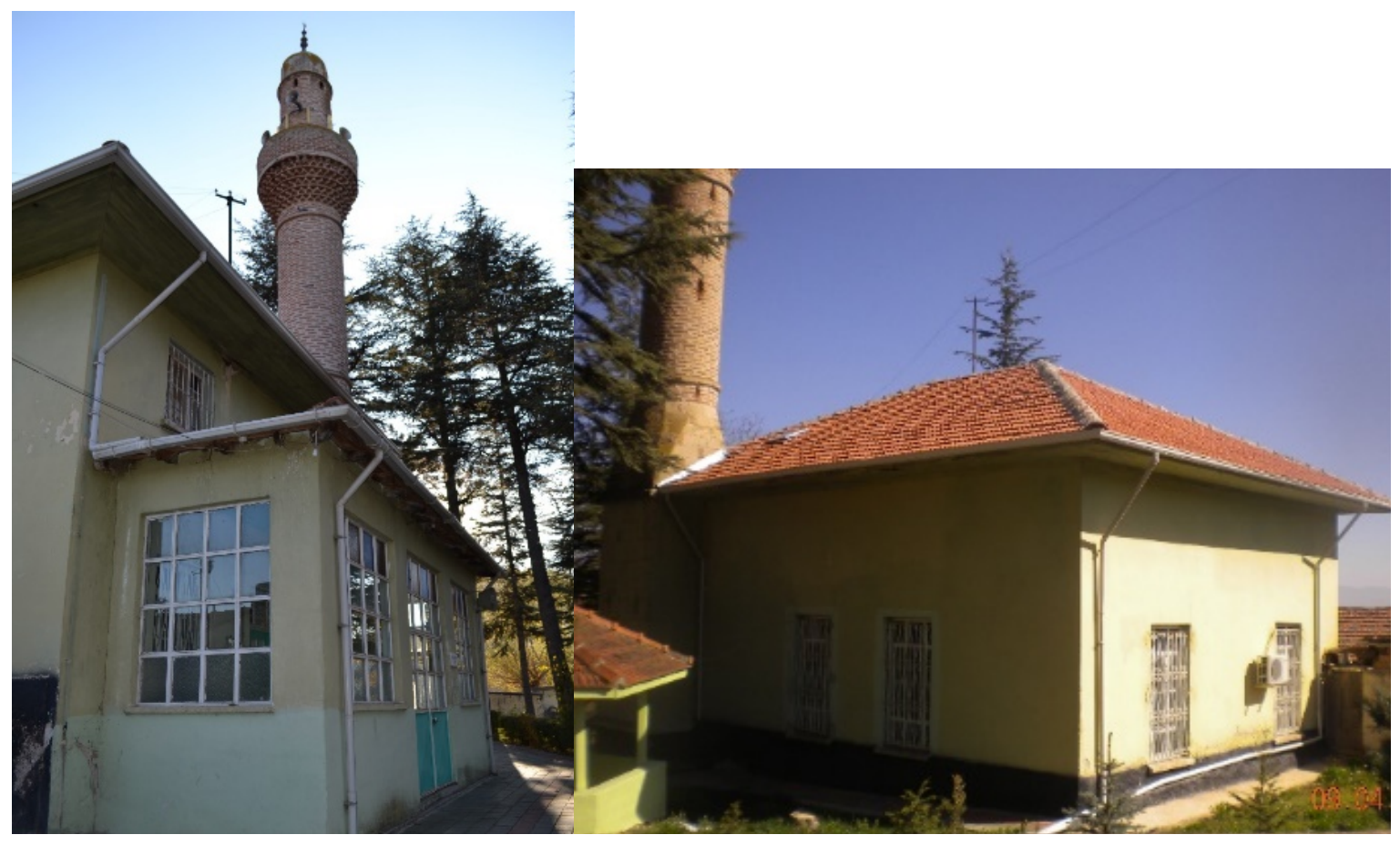


Fotoğraf 3- Karacaşehir Camisi restorasyon öncesi giriş, yan ve arka cepheler

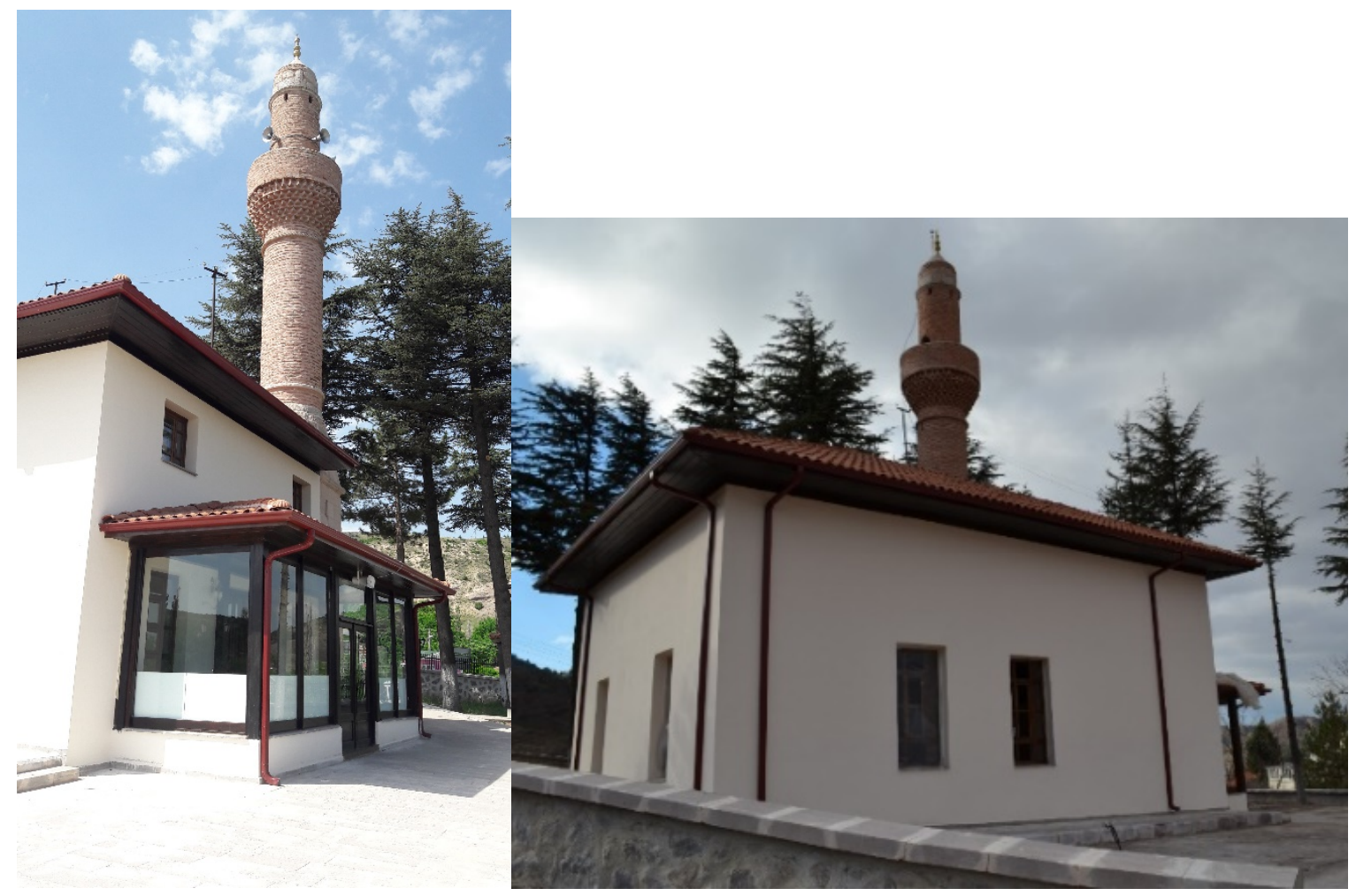

Fotoğraf 4- Karacaşehir Camisi restorasyon sonrası giriş, yan ve arka cepheler

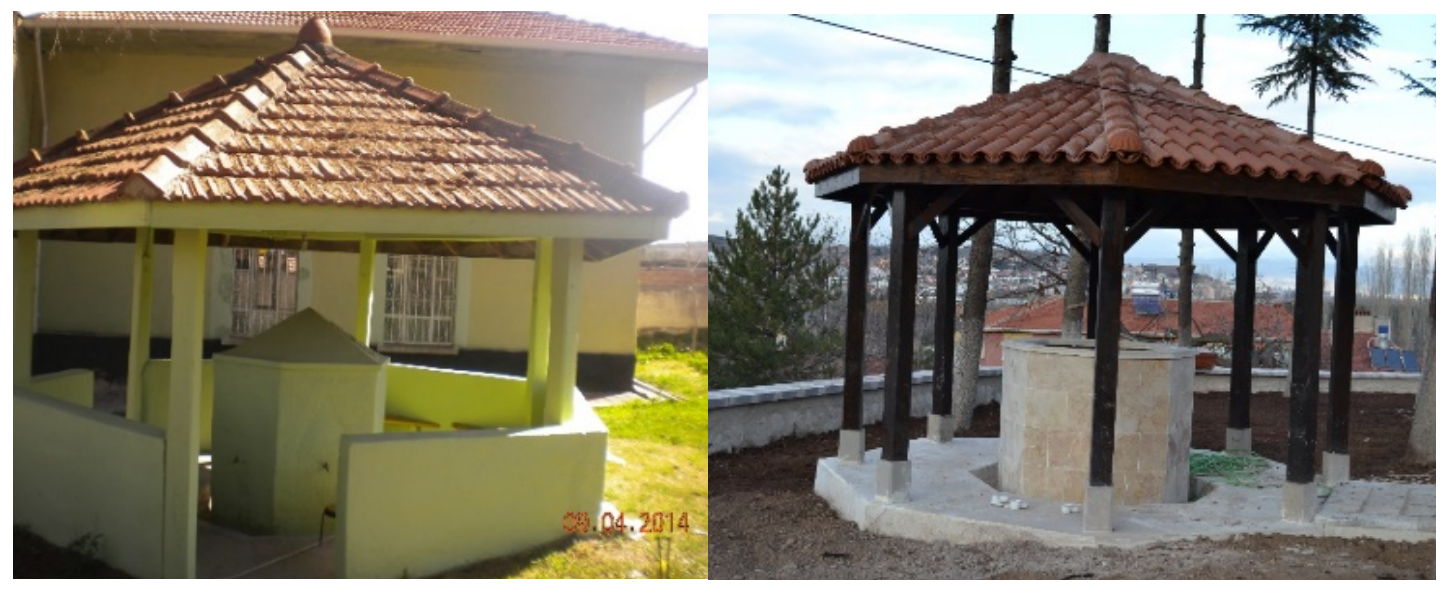

Fotoğraf 5- Karacaşehir Camisi şadırvanı restorasyon öncesi ve sonrası 


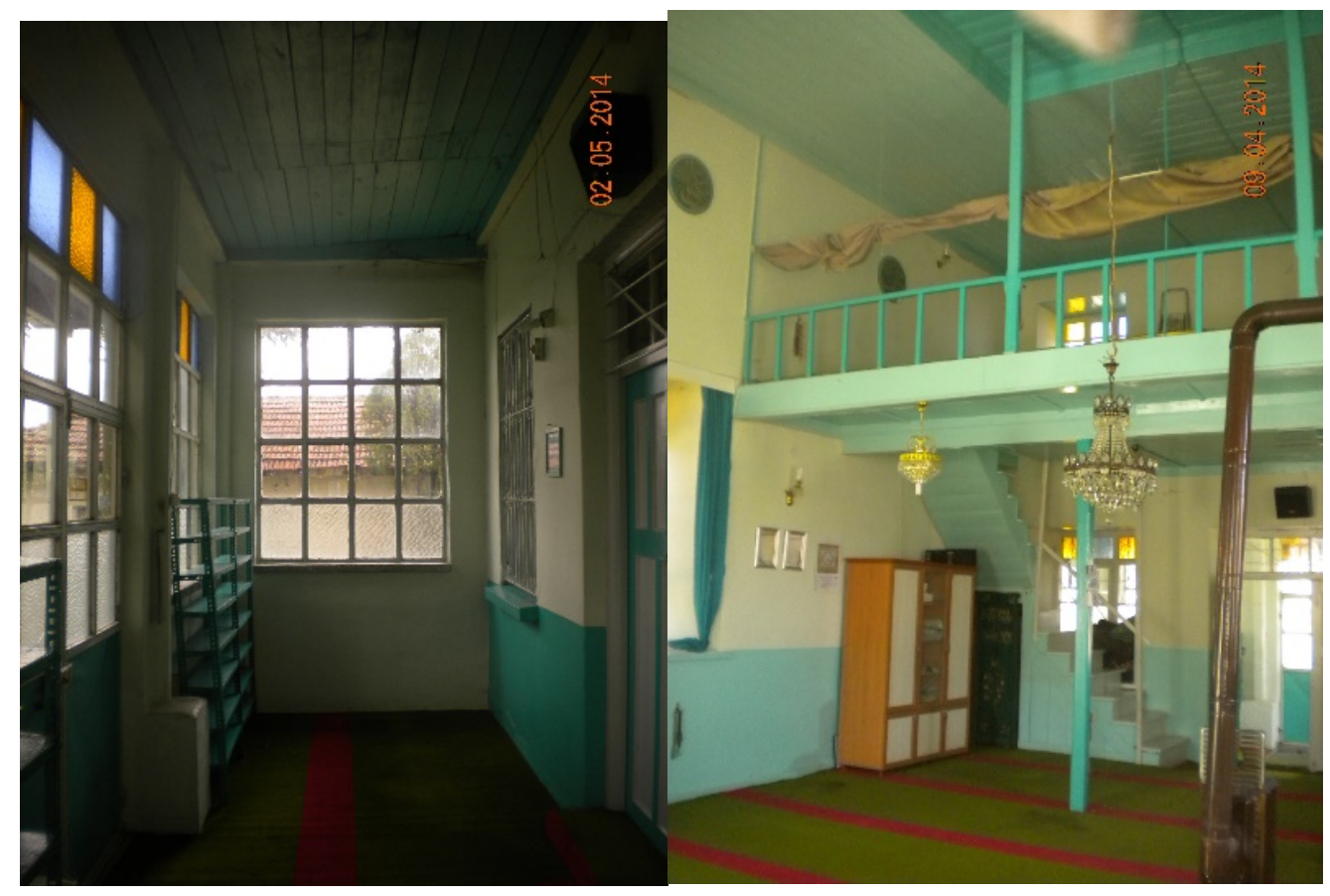

Fotoğraf 6- Karacaşehir Camisi restorasyon öncesi son cemaat yeri ve kadınlar Mahfili

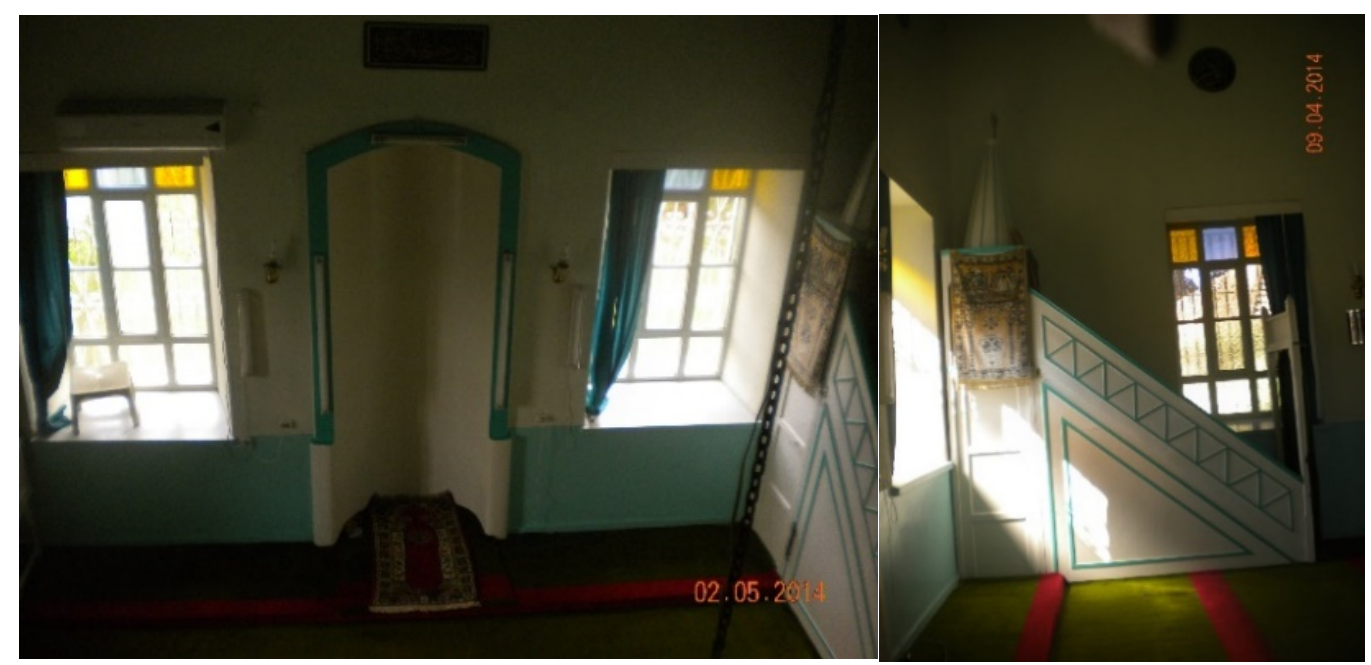

Fotoğraf 7- Karacaşehir Camisi restorasyon öncesi mihrap ve minber

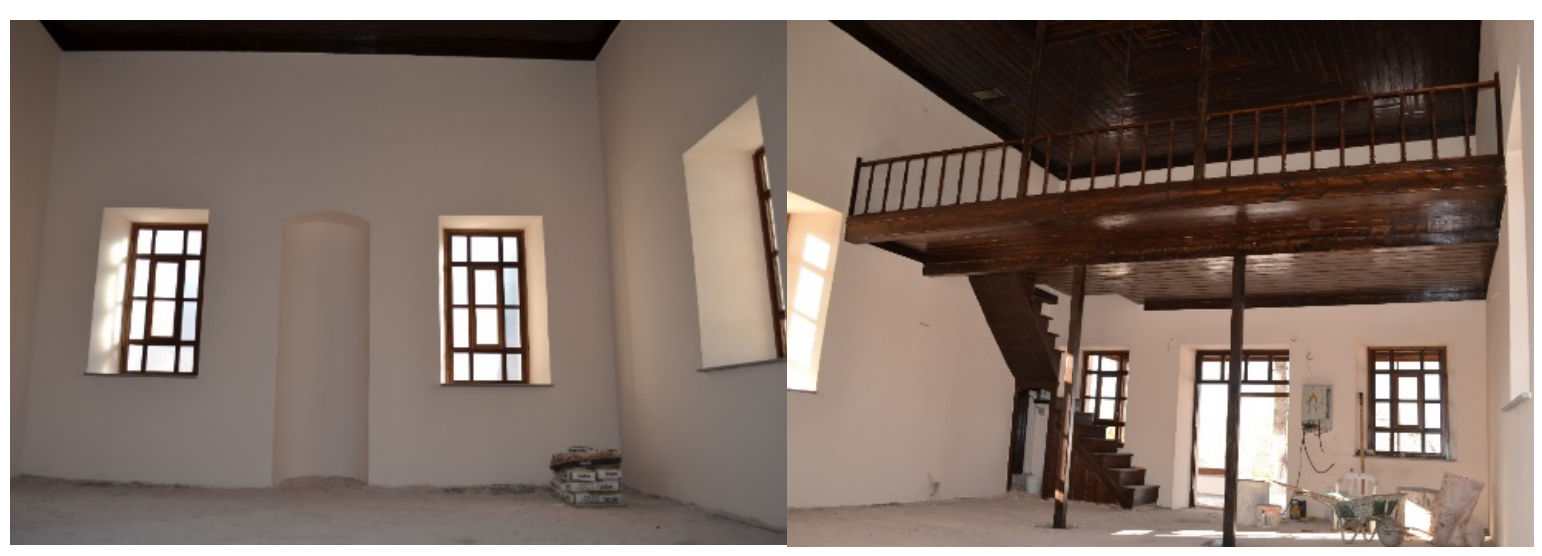

Fotoğraf 8- Karacaşehir Camisi restorasyon sonrası mihrap ve kadınlar Mahfili 

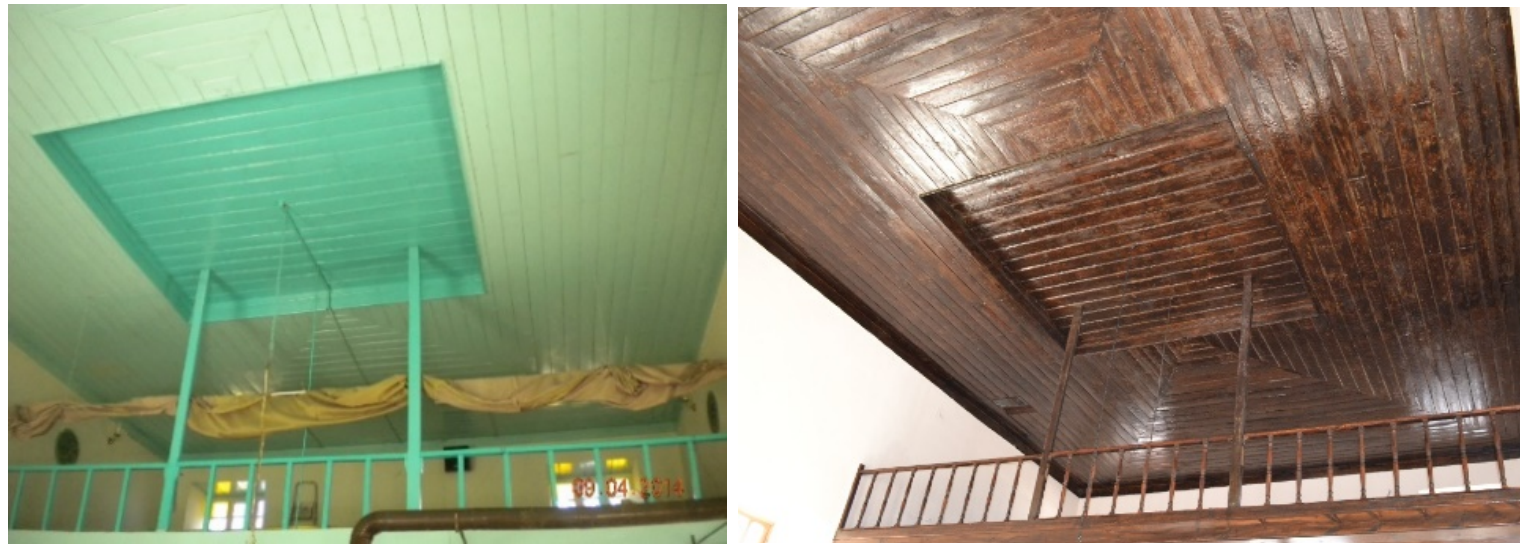

Fotoğraf 9- Karacaşehir Camisi restorasyon öncesi ve sonrası çökertme tavan

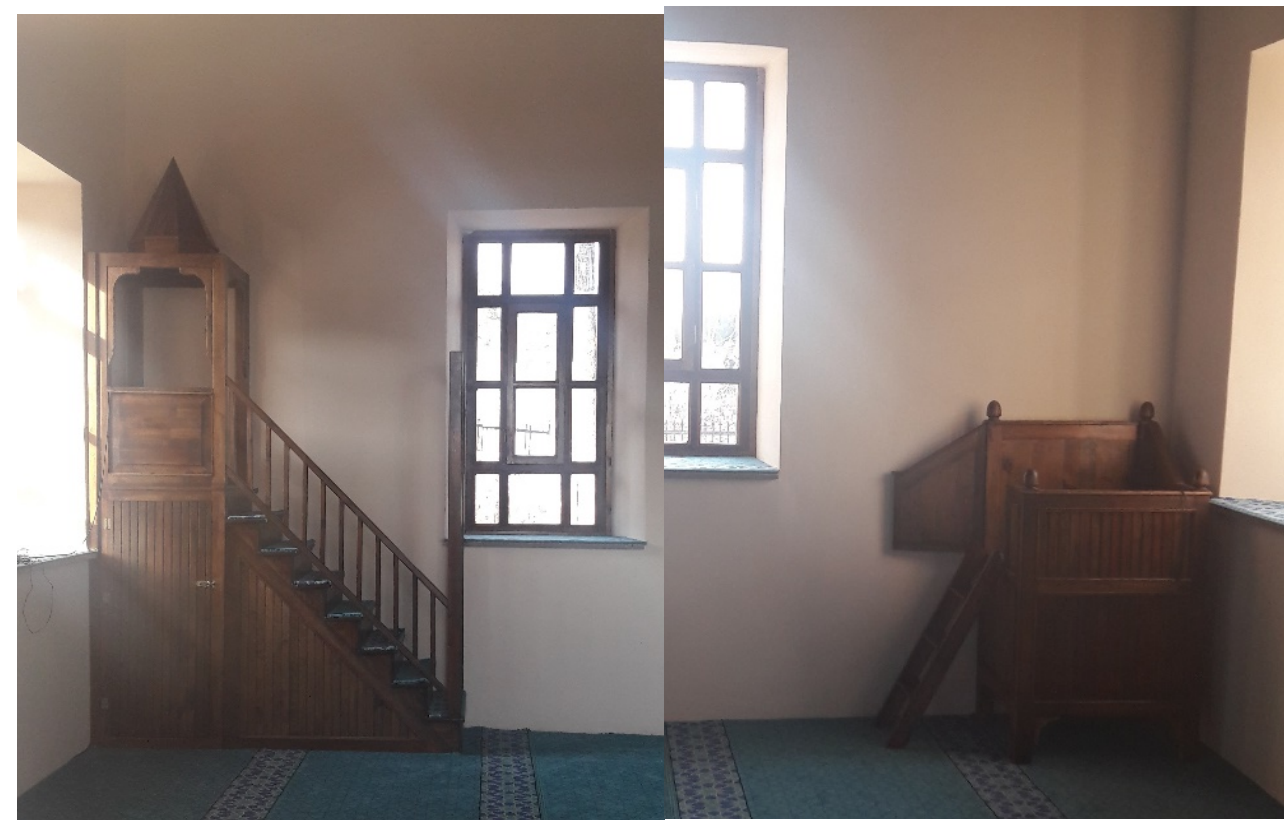

Fotoğraf 10- Karacaşehir Camisi restorasyon sonrası minber ve müezzin kürsüsü
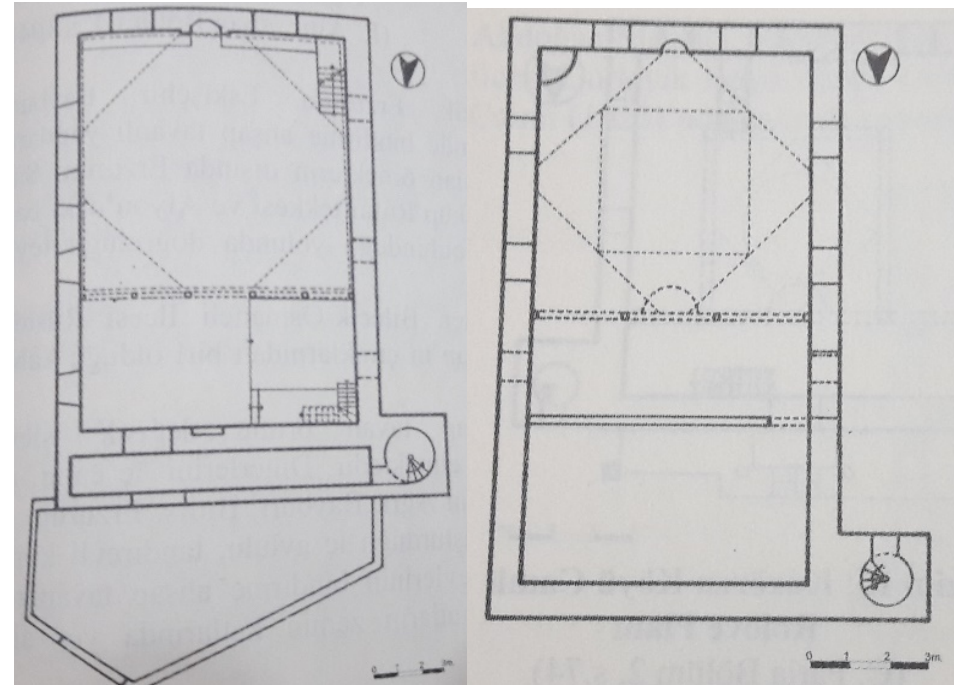

Çizim 5-Eskişehir Dağküplü Köyü Camii ve Gürleyik Köyü Aşağı Mahalle Cami plan (Altınsapan-Parla, 2004 s. 391-392). 


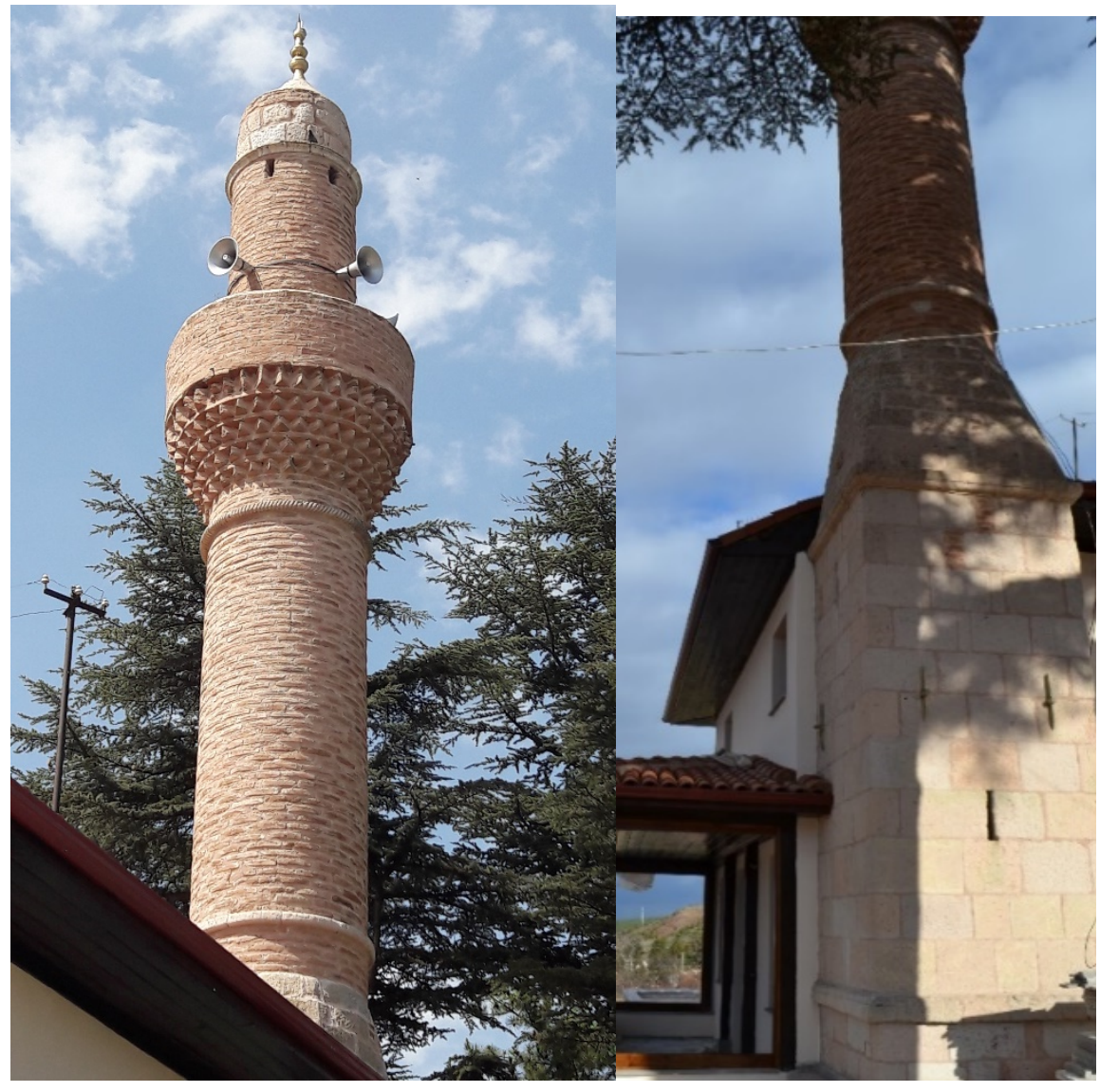

Fotoğraf 11- Karacaşehir Camisi minaresi

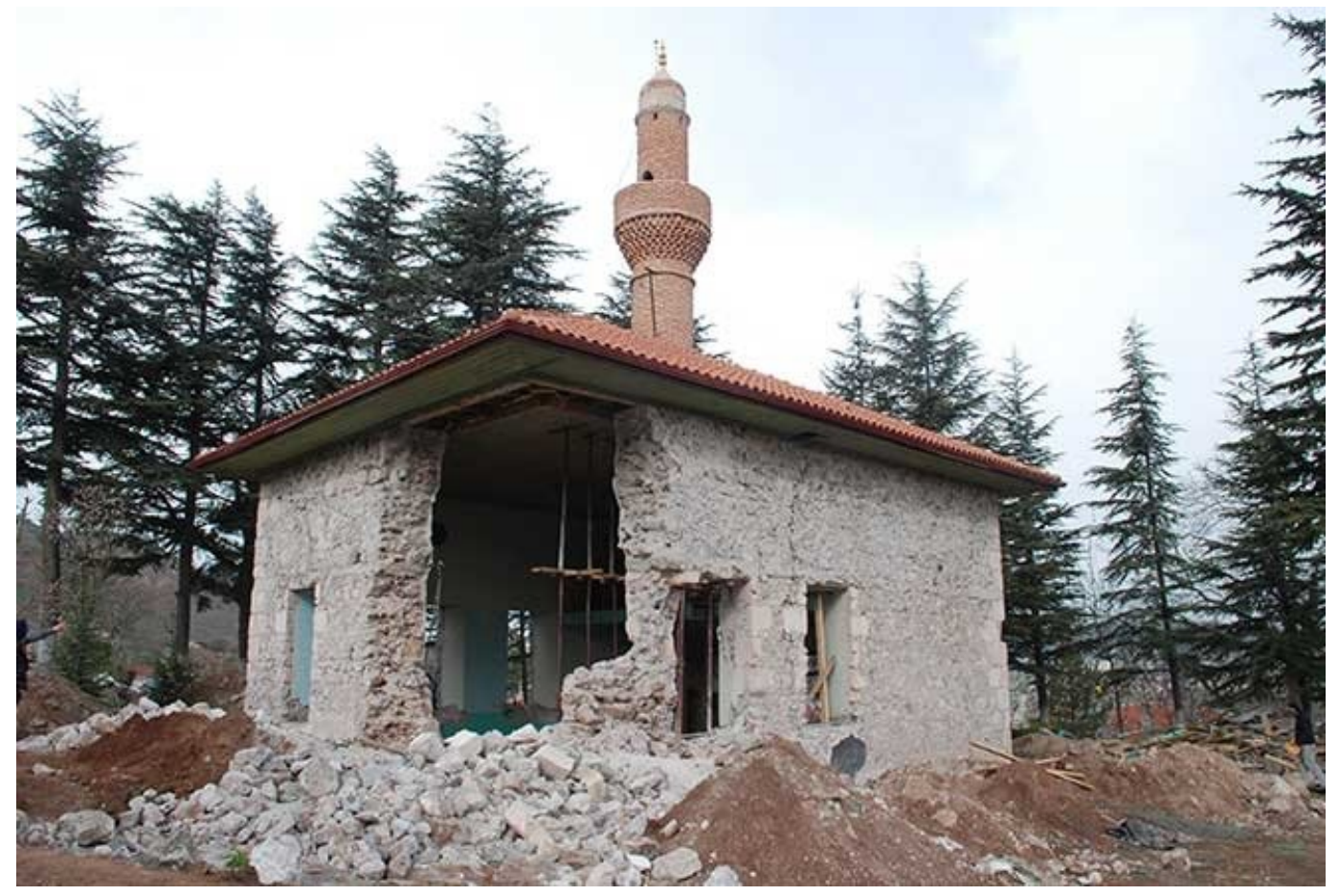

Fotoğraf 12- Karacaşehir Camisi malzeme

(https://www.eskisehir.net/haber/gundem/eskisehir/osmanlinin-ilk-hutbesinin-okundugu-camininicler-acisi-hali- ) (Erişim Tarihi 02/03/2019) 


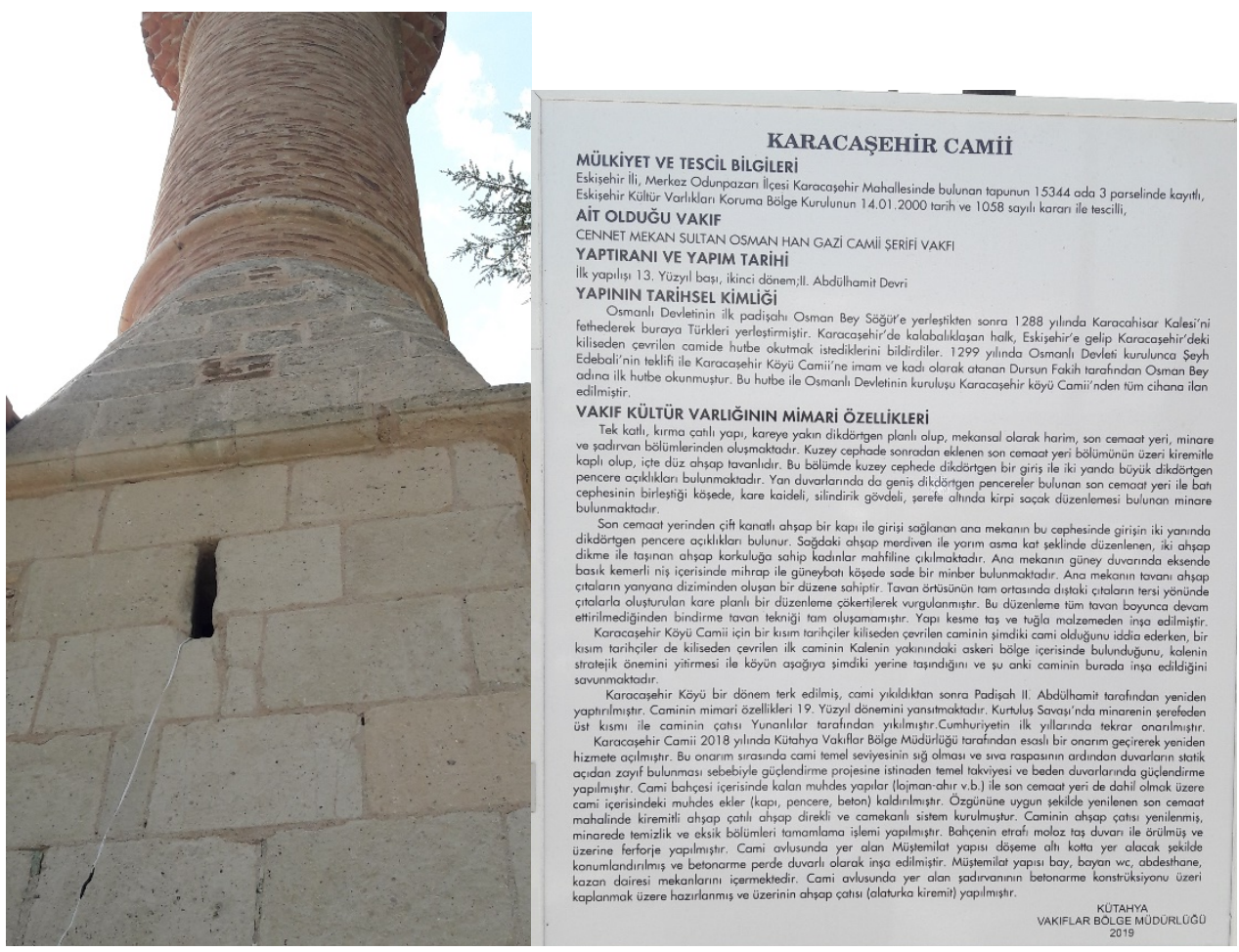

Fotoğraf 13- Karacaşehir Camisi minaresi detay Fotoğraf 14- Karacaşehir Camisi tanıtım levhası

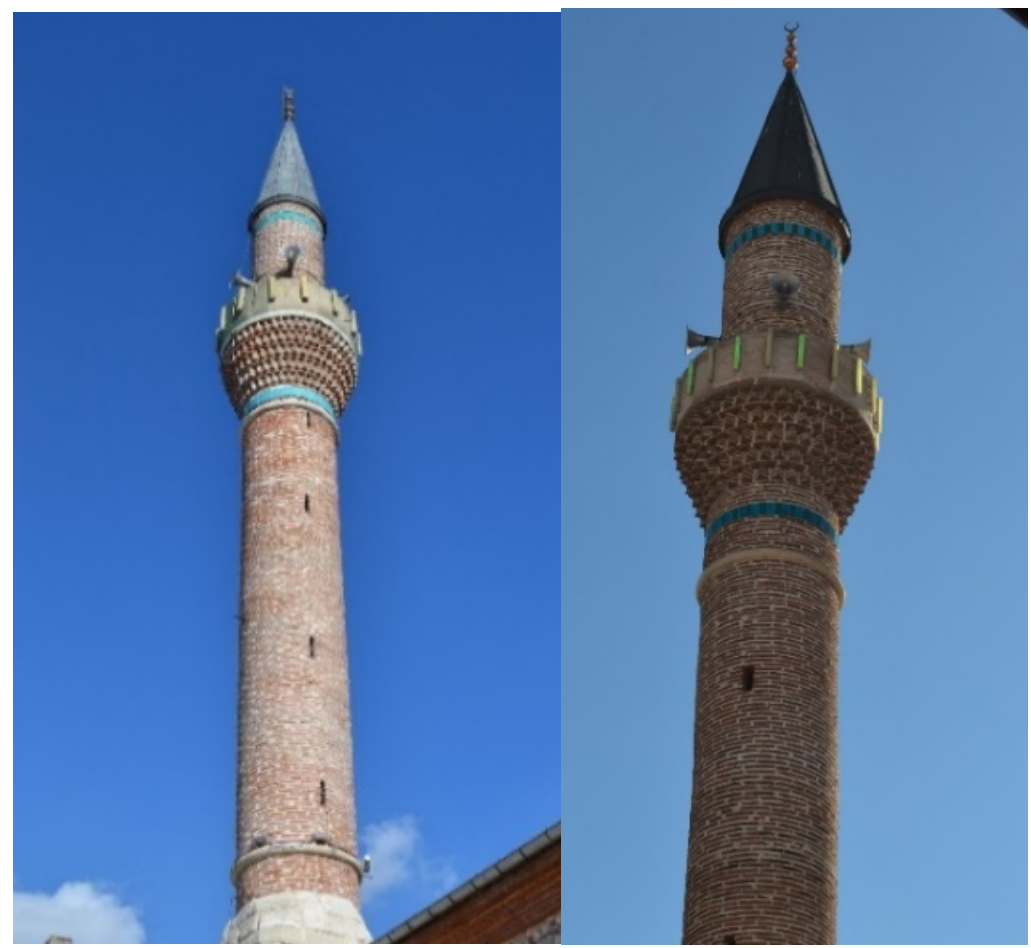

Fotoğraf 15- Tiryakizade Süleyman Ağa Camii

Fotoğraf 16- Orta Işı1k Camii 


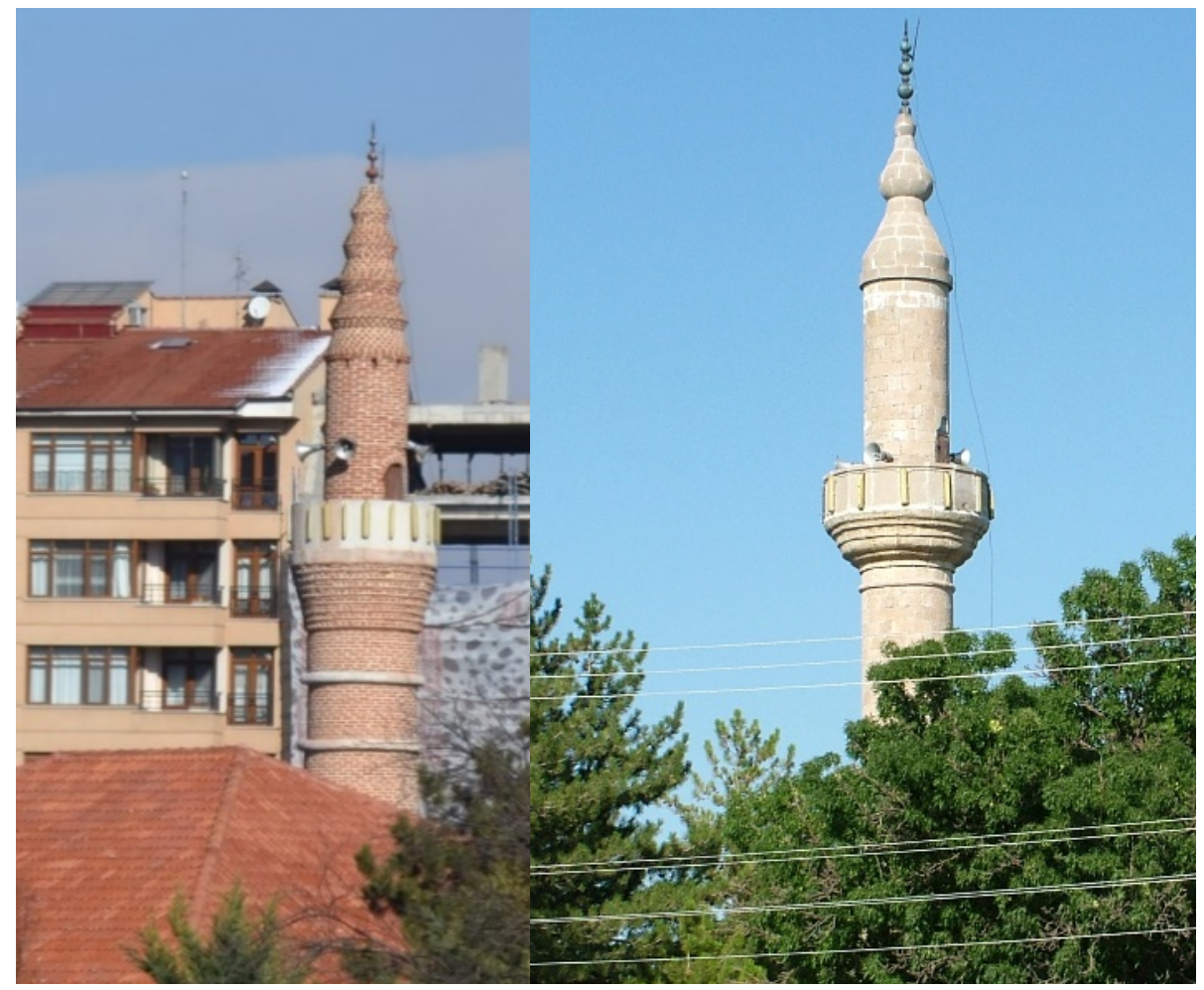

Fotoğraf 17- Alaaddin Camii

Fotoğraf 18- Mahmudiye Hara Camii 